\title{
Pisma Antonija Oreškovića u Arhivu obitelji Brlić kao povijesni izvor
}

U Arhivu obitelji Brlić sačuvana su pisma Antonija Oreškovića Andriji Torkvatu Brliću iz perioda 1857. do 1868. godine. Njihovo poznanstvo i korespondencija od temeljne su važnosti za rekonstrukciju odnosa Narodne stranke s Kneževinom Srbijom i zbivanja u ključnome razdoblju konačnoga državnog preuređenja Habsburške Monarhije 1867. godine, što je dugoročno određivalo i položaj Hrvatske. Narodna stranka i biskup Strossmayer, u to presudno vrijeme za Hrvatsku, svoju politiku su podredili ugovorenomu programu sa Srbijom s ciljem stvaranja nezavisne južnoslavenske države.

Ključne riječi: Antonije Orešković, Andrija Torkvat Brlić, Narodna stranka, biskup Strossmayer, Kneževina Srbija, knez Mihailo Obrenović, Ilija Garašanin, južnoslavenska država

\section{Uvodne napomene}

\section{O Arhivu obitelji Brlić}

Obitelj Brlić ${ }^{1}$ jedna je od najuglednijih i najznačajnijih brodskih obitelji koja je dobro poznata i u širemu hrvatskom kontekstu i od izuzetno je velikoga značenja za povijest hrvatskoga naroda. Nastanivši se u Brodu obitelj je stekla pristojan imetak, ali je ulagala i u obrazovanje svih svojih članova, što im je osiguralo i

\footnotetext{
Ivana Marijić, Antuna Barca 5, 35000 Slavonski Brod, Republika Hrvatska, E-mail adresa: ivana_ mar@yahoo.com

1 Brlići potječu iz Hercegovine odakle su se preselili u Bosnu, a potom u Slavoniju te se nastanili u Svinjaru, današnjemu Davoru. Obitelj se u Brod doselila u prvoj polovici 18. stoljeća. Prvi je došao Mato Brlić. Natpis za nadgrobni spomenik sastavio mu je Matija Antun Relković, što ukazuje na to da je umro kao ugledna osoba. Mramoru studeni! Kog' lad tvoj pokriva? / Nie l' Mato Berlich, sad pod njim počiva / u selu Svinjaru najpri svitlost' vidi / pak u Brod doseli, i u njemu sidi / Zanat habadjinski Mato dobro znade / pošteno se drža, i majstor postade. / Sedam puta deset on živi godina / valjade mu umrit, nemože bit ina / Na smrtnoj postelji, svim blagoslov dili / Andru sina grli, Andro gorko cvili / Mir i ljubav svima Mato priporuči / Tilo zemlji dade, Bogu duh izruči. / 1785. Ignjat Alojzije Brlić, "Uspomene na stari Brod", sv. III, Vijesti: godišnjak Muzeja Brodskog Posavlja 7 (1983): 43.
} 
društveni ugled. Njezini predstavnici dali su u više generacija zapažene pisce, kulturne i političke djelatnike koji su obilježili ne samo povijest Broda na Savi, nego i Hrvatske. Ljubav prema pisanoj riječi i knjizi, žar u sakupljanju, prepisivanju i čuvanju knjiga i svih pisanih dokumenata te raznih zapisa iz života naroda u okolici Broda prenosili su se iz generacije u generaciju i postali tradicija u obitelji čije središnje mjesto zauzimaju treća i četvrta generacija, Ignjat Alojzije Brlić i njegova djeca Andrija Torkvat i Ignjat Brlić. Osobito Andrija Torkvat koji je centralna ličnost u nastanku Obiteljskoga arhiva. Brlići su svojom svestranošću i javnim djelovanjem ostavili vrijedan trag tijekom 19. i početkom 20. stoljeća na hrvatskoj društvenoj, političkoj i kulturnoj sceni te je hrvatskoj kulturi, znanosti, umjetnosti i politici obitelj dala znatan doprinos i ostavila bogato kulturno nasljeđe i spomenike od iznimne vrijednosti. Nesebičnim zalaganjem, predanim radom i sakupljačkim naporom kroz tri stoljeća naraštaji ove, po mnogo čemu izuzetne, obitelji stvorili su Knjižnicu² i Arhiv obitelji Brlić, vrijedne pokretne spomenike hrvatske kulturne baštine.

Arhiv obitelji Brlić3 dragocjen je izvor za različita područja života i vremena tijekom kojega su ga stvarale generacije obitelji Brlić kroz tri stoljeća. U njegovome stvaranju sudjelovali su svi članovi obitelji, a neki od njih uložili su i dodatan napor na očuvanju i prezentaciji baštine javnosti. Plod je to njihova osobnog života i stvaralaštva, sakupljačkih napora i silnoga truda za očuvanje spomena na život koji su stvarali. ${ }^{4}$ Arhiv sadrži građu koja je nastala u razdoblju od 1730. do 2000. godine i koja je svojom vrijednošću daleko nadmašila lokalnu razinu. Temelj te građe i njezin najdragocjeniji dio jest bogata korespondencija. Ona je podijeljena

\footnotetext{
2 Opširnije o značenju Knjižnice obitelji Brlić vidi: Tatjana Melnik, "Knjižnica obitelji Brlić", u: Zbornik o Andriji Torkvatu Brliću. Radovi znanstveno-stručnog skupa održanog 14. studenoga 2008. u Slavonskom Brodu, ur. Dinko Župan (Slavonski Brod: Hrvatski institut za povijest, Podružnica za povijest Slavonije, Srijema i Baranje, 2012), 217-235.

3 Prvu temeljnu informaciju o Arhivu dao je dr. Franjo Bučar 1933. godine. Njegov je članak "Arhiv i knjižnica obitelji Brlić u Brodu na Savi” Ivana Brlić Mažuranić uvrstila u prvi svezak Iz Arhiva obitelji Brlić u Brodu na Savi. Ivanin sin, dr. Ivan Brlić, napisao je članak "O postanku i značenju Arhiva obitelji Brlić” (1943.). Mladen Stanković autor je dviju stručnih knjiga: Obiteljski arhiv Brlić (1974.) i Arhiv obitelji Brlić (1981.). Doprinos upoznavanju Arhiva dao je i dr. sc. Mato Artuković u prilogu "Arhiv obitelji Brlić u Slavonskom Brodu", u: Muzeologija 43-44 (2006 - 2007): 211-226.

4 Ivana Brlić Mažuranić (1874. - 1938.), izdanak ugledne obitelji Mažuranić čiji je najpoznatiji član bio njezin djed, hrvatski ban i pjesnik Ivan Mažuranić (1814. - 1890.), došavši u obitelj Brlić 1892. udajom za brodskoga odvjetnika i političara Vatroslava Brlića s divljenjem i ushićenjem piše svojoj majci o Brlićima: "Ja sam sad tako zaokupljena čitanjem starih pisama da skoro spavati nemogu od nestrpljivosti da se opet zakopam med nje. Ja mislim da bi i tata uživao da to čita. Ovi su stari Brlići (osobito Andrija Torquat, Nacin otac) bili najživahniji, najdarovitiji ljudi koje si pomisliti možete. Ja mislim da nema u svietu tadanjem važnije stvari u koje se nebi bili upleli ni u Monarhiji poznatijeg čovjeka s kojim se nisu dopisivali - opet poglavito Andrija Torquat. Počam od kneza Čartoriskog, do bana Jelačića pak Šokčevića te najraznijih konzula bio je on sa svima na najintimnijem stanovištu obćenja - a uz to nije bilo bosanskog fratra il brodskog obrtnika s kojim nije stajao u kontaktu. Da je sa Jelačićem bio dobar vidi se već iz tog što su ga svi molili kad je trebalo što, kod bana izhoditi ili u audienciju doći." Pismo Ivane Brlić Mažuranić iz 1904. godine u: Artuković, "Arhiv obitelji Brlić”, 220-221.
} 
na dvije skupine. Prvu čini korespondencija među članovima obitelji. Svojom vrijednošću ističu se pisma Ignjata Alojzija Brlića sinovima Andriji Torkvatu i Ignjatu te korespondencija Andrije Torkvata s bratom Ignjatom. ${ }^{5}$ Drugu skupinu čini prepiska članova obitelji s osobama izvan obitelji, koja je izuzetno brojna. Sačuvano je oko tri tisuće pisama, ponajviše Ignjatu Alojziju, Andriji Torkvatu i Ignjatu Brliću. S obzirom na važnu društvenu, političku, književnu i kulturnu ulogu članova obitelji Brlić, ne samo u Brodu nego i šire, Arhiv od najranijih dana sadrži bogatu korespondenciju s uglednicima iz političkoga, kulturnoga, prosvjetnoga, vjerskoga i vojnoga života onodobne Monarhije, od Hrvatske, Austrije, Mađarske do Srbije i Bosne te nema niti jedne ličnosti koja je igrala važniju ulogu na književnome, kulturnome ili političkome polju u 19. stoljeću u Hrvatskoj, a da nije zastupljena bar s jednim pismom u ovome Arhivu. ${ }^{6}$ Posebno je bogata ostavština Andrije Torkvata Brlića, prvenstveno njegova korespondencija, koja predstavlja najdragocjeniju dokumentaciju za hrvatsku povijest u Arhivu s obzirom da je Andrija bio aktivan sudionik svih važnih političkih zbivanja u Hrvatskoj i Habsburškoj Monarhiji sredinom 19. stoljeća. Zahvaljujući političkim ulogama i funkcijama koje je obnašao ostvario je prijateljstva i poznanstva s gotovo svim važnim osobama hrvatskoga kulturno-političkog života, ali i na međunarodnoj pozornici s važnim osobama europske politike te njegova korespondencija iz tih veza čini najvažniji dio Arhiva. Obiteljska pisma, bogata korespondencija koja je ostala iza njegovih prijateljstava i poznanstava s najznačajnijim ljudima toga vremena i Dnevnik koji je vodio od 1844. do 1857. godine, predstavljaju prvorazredne povijesne izvore. Andrija je sve zapisivao i o svim najutjecajnijim ljudima tadašnje političke scene. S obzirom da je, kako je već rečeno, bio sudionik svih važnijih događaja na političkoj sceni Habsburške Monarhije od 1848. do svoje smrti 1868., dokumentacija koju je ostavio iza sebe od izuzetne je vrijednosti za povijesna istraživanja. Njegov Dnevnik važan je napose za hrvatsku povijest 1848. godine, jer je kao Jelačićev tajnik i izaslanik u Parizu imao uvid u gotovo sva bitna zbivanja. A o vrijednosti prepiske svjedoče samo neka od najvažnijih imena osoba s kojima je bio u korespondenciji: biskup Josip Juraj Strossmayer, biskup Juraj Haulik, ban Josip Jelačić, Ivan Kukuljević Sakcinski, Vatroslav Lisinski, Bogoslav Šulek, Matija Mesić, Ante Starčević, Petar Preradović, Vjekoslav Babukić, Franjo

\footnotetext{
5 Od posebnoga su povijesnog značenja pisma Ignjata Alojzija sinu Andriji Torkvatu. Korespondencija se vodila na latinskome, njemačkome i hrvatskome jeziku. U pismima, osim savjeta sinu, iznosi i razmišljanja o političkim, kulturnim i društvenim zbivanjima svoga vremena i znamenitim suvremenicima te su pisma koristan izvor za upoznavanje hrvatske povijesti 19. stoljeća. Dr. Ivan Brlić objavio je 1942. prvu knjigu, a 1943. godine i drugu knjigu Ignjat Alojzije Brlić: Pisma sinu Andriji Torkvatu 1836-1855. U izdanju Hrvatskoga instituta za povijest, Podružnice za povijest Slavonije, Srijema i Baranje objavljena je 2015. godine i prva knjiga izvorne građe Korespondencija Andrije Torkvata i Ignjata Brlića, Pisma 1846.-1856., prir. Mato Artuković, Vlasta Švoger i Mica Orban Kljajić.

6 Dr. Franjo Bučar, "Arhiv i knjižnica obitelji Brlić u Brodu na Savi", u: I. B. Mažuranić, Iz Arhiva obitelji Brlić u Brodu na Savi (Uvod k zbirci starih pisama od god. 1848.-1852.) (pretiskano iz Obzora) (Zagreb: Tipografija d.d., 1934), 35.
} 
Rački, knez Adam Czartoryski i Ladislav Czartoryski, Robert Cyprien, Vuk Stefanović Karadžić, Jovan Jovanović Zmaj, Antonije Orešković, fra Grga Martić, Josip Stadler, Ambroz Vraniczany, Janko Drašković, Matija Mrazović, Gjuro Pilar, Milan Amruš, Mirko Bogović, Tomo Skalica.

Bogatstvu i vrijednosti Arhiva pridonijela je i Ivana Brlić Mažuranić posebno sa svojom bogatom korespondencijom s roditeljima, suprugom i djecom, literarnom korespondencijom vezanom za objavljivanje i prijevode njezinih djela te rukopisnom književnom ostavštinom. Sačuvani su uglavnom svi rukopisi njezinih djela. Dolaskom u Brod na Savi Ivana je, živeći u intelektualno poticajnoj sredini, u kući Brlićevih uz bogatu kulturnu i nacionalno-političku tradiciju obitelji našla plodno tlo i za svoj kulturni i bogati književni rad.7 Uočavajući dokumentarnu vrijednost Arhiva i baštine obitelji Brlić, prihvatila se sustavnoga sređivanja postojeće građe koju je zatekla i njezina publiciranja te je postavila temelje današnjega Arhiva obitelji Brlić. ${ }^{8}$

Sva sačuvana građa Arhiva ${ }^{9}$ predstavlja koristan izvor informacija za društvenu, političku, gospodarsku, kulturnu, prosvjetnu i vjersku povijest. Otkriva mentalitet vremena, daje opsežan i vjeran prikaz maloga građanstva u Hrvata kroz gotovo dva stoljeća kao i prikaz razvoja političke i kulturne misli. Razgovori Brlićevih s njihovim suvremenicima ne vode nas samo u sve kulturne, političke i društvene prilike u Hrvatskoj, nego i u sva ona kretanja koja su u tome razdoblju potresla Europu.

\section{Andrija Torkvat Brlić i Antonije Orešković}

Među sačuvanom građom u Arhivu nalaze se i pisma časnika srpske vojske i povjerenika srpske Vlade Antonija Oreškovića upućena političaru i publicistu Andri-

7 U svojoj je autobiografiji iz 1916. godine, koja je prvi put objavljena u Hrvatskoj reviji 1930., zapisala: “(...) došla sam u stari dom obitelji Brlićeve u kojoj sve odaje koliki su interes članovi te obitelji gojili za umjetnost i književnost, za svaki patriotski i lijepi pokret. Majka mog supruga, Franjka rođena pl. Daubachy (spominje se u knjižici Ivana Kukuljevića Südslawische Künstler) bila je slikarica finog i ukusnog kista, te je ostavila svoj dom okićen mnogobrojnim uresom, akvarelima, crtežima i uljenim slikama. Uređena obilna knjižnica sabrana Ignjatom Alojzijem Brlićem, zatim njegovim sinovima Andrijom Torkvatom i Ignjatom, koju sam zatekla, sastoji se iz djela sviju jezika - a uz to iz rukopisne zbirke, a ponajpače iz zbirke korespondencije od god. 1726.-1860. Ta zbirka sadržava do tisuću pisama, među njima su listovi gotovo sviju istaknutih ličnosti našeg javnog života, od sto godina amo. Kolika obilna hrana za moja literarna nagnuća!” I. B. Mažuranić, “Autobiografija”, u: Vinko Brešić, prir., Autobiografije hrvatskih pisaca (Zagreb: AGM, 1997), 525.

8 Pokrenula je seriju članaka u Obzoru objavljujući dijelove građe Arhiva koji su potom 1934. i 1935. godine pretiskani u posebne knjige Iz Arhiva obitelji Brlić u Brodu na Savi, sv. I-III. Prvi svezak je Uvod $k$ zbirci starih pisama od god. 1848.-1852., a u drugome i trećemu svesku objavila je Ulomke dnevnika Andrije Torkvata Brlića iz 1848. - 1849. u uvjerenju da su oni vrlo važni za hrvatsku povijest.

9 Danas je Arhiv u vlasništvu obitelji Ružić i pod skrbi dr. sc. Mate Artukovića, kojega je za to ovlastila upravo obitelj Ružić. Fond Arhiva je 2002. godine mikrofilmiran i u tome je obliku dostupan javnosti u Državnome arhivu u Slavonskome Brodu, Arhivu obitelji Brlić i u Hrvatskome državnom arhivu u Zagrebu. Građa je nakon mikrofilmiranja vraćena u Hrvatski institut za povijest, Podružnicu za povijest Slavonije, Srijema i Baranje u Slavonskome Brodu. 
ji Torkvatu Brliću. Korespondencija između njih dvojice važna je za rekonstrukciju odnosa između Narodne stranke i Vlade Kneževnine Srbije u ključnome razdoblju preustroja Habsburške Monarhije. Ta nam pisma pomažu razumjeti, za hrvatsku stranu, nepovoljan ishod pregovora oko Hrvatsko-ugarske nagodbe. Orešković je bio, preko Andrije Torkvata, veza biskupa Josipa Jurja Strossmayera i Narodne stranke s Ilijom Garašaninom i Vladom Kneževine Srbije. Preko Oreškovića je srpska Vlada predložila Strossmayeru da zajedno rade na stvaranju južnoslavenske države koja bi bila neovisna i od Habsburške Monarhije i od Osmanskoga Carstva. Strossmayer je pristao da Narodna stranka radi na ostvarenju toga političkog programa. Program, koji je Orešković izradio, predviđao je dizanje ustanka u Bosni u ljeto 1867. godine i njezino oslobađanje od turske vlasti te stvaranje južnoslavenske države kao krajnji cilj akcije. Narodna stranka u ugovoru sa srpskom Vladom obvezala se da će u svojemu političkom djelovanju u Monarhiji izbjegavati savez is Bečom i s Peštom. ${ }^{10}$ Upravo su zato Oreškovićeva pisma dragocjen izvor za istraživanje tih zbivanja, koja su se pokazala presudnima za vrijeme kada su se polagali trajni temlji za konačni preustroj Habsburške Monarhije i kada se dugoročno odlučivalo o položaju Hrvatske u njoj.

Andrija Torkvat Brlić ${ }^{11}$ središnja je ličnost obitelji Brlić u kojoj obiteljski talent i interes za intelektualni rad i napredak doživljava svoju snažnu kulminaciju. Rođen je 15. svibnja 1826. u Brodu od majke Katarine iz vukovarske obitelji Benko i oca jezikoslovca i trgovca Ignjata Alojzija Brlića. Bio je svestrano obrazovan i poliglot. ${ }^{12}$ Zahvaljujući očevu shvaćanju potrebe i vrijednosti obrazovanja te njegovoj brizi za intelektualnim rastom članova obitelji, Andrija je stekao visoko obrazovanje na uglednim europskim sveučilištima.

Završivši osnovno obrazovanje u Brodu, upisao se u nižu gimnaziju u Vinkovcima (1837./1841.) iz koje je izašao kao najbolji učenik svoje generacije. Dvogodišnju višu gimnaziju završio je u Zagrebu (1841./1843.). Tu je kao šesnaestogodišnjak ${ }^{13}$

$\overline{{ }^{10} \text { Grgur Jakšić, Vojislav Vučković, Spoljna politika Srbije za vlade kneza Mihaila (Prvi balkanski savez) }}$ (Beograd: Istorijski institut, 1963), 356-363. Vidi i Vera Ciliga, Slom politike Narodne stranke (18651880) (Zagreb: Matica hrvatska, 1970), 36-37.

${ }^{11}$ Za detaljan prikaz života i javnoga djelovanja Andrije Torkvata Brlića na političkome, književnojezikoslovnome, publicističkome, gospodarskome i administrativno-tajničkome području vidi: Vlasta Švoger, Ideali, strast i politika. Život i djelo Andrije Torkvata Brlića (Zagreb; Slavonski Brod: Hrvatski institut za povijest, Podružnica za povijest Slavonije, Srijema i Baranje, 2012).

${ }_{12}$ Govorio je njemački, mađarski, poljski, češki, francuski, pomalo i engleski, a vladao je i klasičnim jezicima, latinskim i grčkim. Švoger, Ideali, strast i politika, 24.

${ }^{13}$ U duhu obiteljske tradicije književnoga djelovanja Andrija je već tada kao šesnaestogodišnjak objavio svoju prvu pjesmu Pozdrav Danici u Danici ilirskoj, 1842. U pismu iz veljače 1842. godine Ignjat Alojzije piše sinu o majčinome veselju i ponosu povodom objavljivanja njegove pjesme: "[...]Materi nema većeg veselja nego sada u Danicu zagledat, dakle joj još koje veselje učini, al takia 2-3 Exemplara pošalji da se može hvaliti. [...] Mati te imenuje: sunašce moje žarko! Golube moj sladki! Hrano moja lipa! U s.w. jer si joj u Danici veselje učinio." Ignjat Alojzije Brlić, Pisma sinu Andriji Torkvatu 1836-1855, knj. I (Zagreb: Hrvatski izdavalački bibliografski zavod, 1942), 41-42. Andrija je nastavio pisati uglavnom domoljubnu i ljubavnu liriku, a bavio se i prevoditeljskim radom. U Zori dalmatinskoj objavio je prijevod odlomka iz 
ostvario poznanstva s prvacima hrvatskoga narodnog preporoda i istaknutim intelektualcima tadašnjega hrvatskog javnog života s kojima je surađivao njegov otac: sa Šulekom, Demetrom, Kukuljevićem, Babukićem i Strossmayerom - otprije kućnim prijateljem obitelji Brlić. Upoznaje se i zanosi idejama hrvatskoga narodnog preporoda koje snažno utječu na njega ${ }^{14}$ Kao iznimno talentiranoga gimnazijalca biskup Haulik poslao ga je 1843. godine u Beč na studij teologije. Zahvaljujući očevim vezama u Beču je došao u kontakt s vodećim slavenskim intelektualcima, sve je više jačao njegov interes za politiku te postaje vatreni "Ilir". ${ }^{15}$ U Beču se Andrija našao u vrtlogu političkih događanja, što je ostavilo snažan dojam na njega i usmjerilo ga u svjetovne vode. Revolucionarna 1848./'49. godina uvelike je promijenila smjer njegova života. Napustio je svećenički poziv i uključio se u politički život. Dane pobune provodio je na bečkim ulicama. Sveslavenski i revolucionarni zanos odveo ga je u Prag na Slavenski kongres. U praškoj pobuni borio se na barikadama na strani čeških prosvjednika, a sudjelovao je i u slovačkome ustanku. U prosincu 1849. godine otišao je u Pariz kao Jelačićev izaslanik. ${ }^{16}$ Nastojeći uvjeriti u potrebu federalističkoga preuređenja Monarhije,

Homerove Ilijade, što je prvi prijevod nekoga Homerovog teksta na hrvatski jezik. Švoger, Život i djelo A. T. Brlića, 84 .

${ }_{14}$ Njegov karakter i zanos slavenskim idealizmom dobro se oslikava iz pisma koje mu je u ožujku 1842. uputio otac i u kojemu ga upozorava i poziva na razboritost: "Dobro ja znam da su Mađari naši progonitelji, da nam jezik i narodnost oteti nastoje - zato jim se imamo otprti i braniti se i nogama i rukama, $s$ pameću i krepošću - ali sve razborito, i kad je čemu doba, tiho mirno, pritajeno. Ali tako ludovat mogu samo budale i vitrogonje; ti znaš da sam te ja u Zagreb dao, da postaneš Ilir, da ti se ljubav k rodu i narodnosti u mlado srce usije i danas sutra razboriti plod donese; nije pako moja želja i volja da ti fanatikus postaneš i svrhu tog pamet izgubiš i mene potom ovako žalostiš i vrijeđaš. [...] Gledaj ti sve s pameću nadhitit, pak ti nije potreba budalit, pametni ljudi misle, i nahode si malih duhovah (kao što si ti sada) i s njima, kao s' kakvim oruđem, rade što im volja. Tvoj otac hoće i želi da budeš upravitelj a ne oruđe." Brlić, Pisma sinu, 43-44.

15 Otac ga i za boravka u Beču ne prestaje opominjati i koriti zbog njegove naglosti i vatrenoga temperamenta. U listopadu 1843. godine piše sinu: "Okani se vatrenog Ilirizmusa i Slavizmusa, sve lagano, dalje se dolazi." U pismu iz studenoga 1843.: “Takodjer te opominjem, da buduć u ungarskom Institutu, Magjare s' mirom ostaviš, ne znaš bo odkuda te guja ujisti može. Ljubi tvoju domovinu domorodce i domorodni jezik - al se okani vatrenosti, i nagle i žestoke Iliromanije, jer to k’ dobru nevodi." Brlić, Pisma sinu, 64, 68.

16 Poljska emigracija, okupljena oko kneza Adama Czartoryskog sa sjedištem u hotelu Lambert u Parizu, nastojala je preko svojih agenata pridobiti vođe Južnih Slavena i Mađara za kompromis i zajedničku borbu protiv Austrije. Jelačić je, znajući da djeluju uz potporu francuske Vlade, kao posebnoga emisara u Pariz poslao Andriju Torkvata, koji je znao poljski, a bio je i povezan sa simpatizerima Hotela Lambert iz redova studenata u Beču. Zadatak mu je bio, u granicama odanosti prema Austriji, predstaviti Jelačićeva stajališta francuskoj Vladi i poljskim emigrantima, raditi na suzbijanju mađarske protuhrvatske propagande i nagovoriti poljsku emigraciju da napusti svoje mađarofilstvo i prihvati ideju jedinstvene, federativne i antiruske usmjerene Austrije. Dr. Rudolf Maixner, Andrija Torkvat Brlić emisar bana Jelačića u Francuskoj, Iz Arhiva obitelji Brlić u Brodu na Savi, sv. IV., prev. Zora Milčić-Brlić (Zagreb: Tipografija d.d., 1939), 10-11. Drugo Brlićevo putovanje u Pariz i zapadnoeuropske zemlje (Belgiju, Veliku Britaniju, Švicarsku i sjevernu Italiju) financirao je biskup Strossmayer. Brlić je otputovao u Pariz u proljeće 1850. godine, no ovoga puta nije išao s političkom misijom, nego kako bi upoznao politički, upravni i sudski ustroj tih zemalja te njihovu kulturu, gospodarstvo i društvene odnose. O tome opširnije u: Maixner, A. T. Brlić u Francuskoj, 52-59. Vidi i Piotr Żurek, Poljska i Poljaci u životu Josipa Jurja Strossmayera (Slavonski Brod: Hrvatski institut za povijest, Podružnica za povijest Slavonije, Srijema i Baranje, 2008), 40-49. i Švoger, Život i djelo A. T. Brlića, 37-40, 98-101. 
intenzivno je komunicirao s Czartoryskim i ostalim istaknutim pripadnicima kruga oko Hotela Lambert. Primili su ga i predsjednik Francuske Republike Louis Napoleon, ministar vanjskih poslova, papinski nuncij i turski poslanik. Međutim, Brlićeva je misija kasnije skrenula u protuaustrijskome smjeru. Kontakti s poljskom emigracijom i nove političke okolnosti, prvenstveno centralistička politika austrijske Vlade, doveli su do promjena njegovih političkih stajališta pa sada prihvaća koncepciju Hotela Lambert o potrebi pomirenja Hrvata i Mađara. Budući da misija u Parizu nije urodila željenim plodom i da hrvatski politički čimbenici koji su mu financirali put nisu bili zadovoljni njegovom djelatnošću u Parizu, pozvan je da se vrati natrag. Nakon sloma revolucije i uspostave neoapsolutizma bio je pod stalnim policijskim nadzorom. Nakon burne 1848. i 1849. godine Andrija se vratio u Zagreb i posvetio književnosti zamijenivši političku aktivnost djelovanjem u kulturi. Na poziv biskupa Strossmayera odlazi u Đakovo biti provizor vlastelinstva biskupije u Đakovu i biskupov tajnik. Međutim, 1853., zbog nezadovoljstva odnosima na vlastelinstvu, ali i zbog nedostatka vremena za književni i znanstveni rad, napušta Đakovo. Odlazi u Beč na studij prava. Nakon završetka studija 1857. godine vratio se u Brod gdje je otvorio odvjetnički ured te se posvetio i istraživanju povijesti hrvatskoga i drugih južnoslavenskih naroda. Nakon obnove ustavnosti u Monarhiji ponovno se uključio u političke aktivnosti. Izabran je za zastupnika Vojne krajine u Hrvatskome saboru 1861. godine te je predvodio deputaciju krajiških zastupnika u Beču bezuspješno traživši od cara sjedinjenje Vojne krajine s Hrvatskom i Slavonijom. U listopadu 1861. oženio se zagrebačkom slikaricom i plemkinjom Fanikom Daubachy, ${ }_{17}$ koja mu je rodila sinove Vatroslava i Dobroslava te kćer Tugomilu. ${ }^{18}$ Umro je u rodnome gradu u svibnju 1868. u 42. godini života.

Andrijina politička djelatnost uključivala je i njegov rad na ujedinjenju južnoslavenskih naroda. U literaturi su poznate njegove veze s tajnom beogradskom organizacijom "Propaganda" čiji je bio član aktivno sudjelujući u Garašaninovoj $^{19}$ politici na prostoru turske Bosne i u Hrvatskoj. Kao agent "Propagande",

\footnotetext{
${ }_{17}$ Njihovo poznanstvo datira još od 1849. godine kada ih je, nakon Andrijinih političkih misija po Europi i povratka kući, upoznao Ivan Kukuljević Sakcinski.

18 Mladen Stanković, Arhiv obitelji Brlić (Slavonski Brod: GRO “Plamen”, 1987), 25.

19 Ilija Garašanin (1812. - 1874.), srpski političar, autor velikosrpskoga programskog spisa Načertanije (1844.). Poslije odlaska kneza Miloša iz Srbije (1839.) napušta državnu službu. Dolaskom Aleksandra Karađorđevića na vlast Garašanin opet stupa na političku pozornicu. Devet godina nalazio se na čelu Ministarstva unutarnjih poslova (1843. - 1852.), a potom je kratko vrijeme obnašao dužnost predsjednika Vlade i ministra vanjskih poslova (1852. - 1853.). Otpušten je pod snažnim pritiscima Rusije zbog okretanja prema Francuskoj i veza s antiruski raspoloženom poljskom emigracijom te se nekoliko godina nalazio izvan političkoga života. Početkom 1858. vraćen je na položaj ministra unutarnjih poslova. Iste godine organizirao je Svetoandrejsku skupštinu na kojoj je zbačen knez Aleksandar i dinastija Karađorđević te postavljena konkurentska dinastija Obrenović, a za kneza Miloš Obrenović. Godine 1861. Garašanin postaje predsjednik Vlade i ministar vanjskih poslova. Na toj dužnosti ostaje do studenoga 1867. kada je otpušten iz službe. Petar Šimunić, "Načertanije" - Tajni spis srpske nacionalne i vanjske politike, 2. izdanje, ur. Željko Krušelj (Zagreb: Globus, 1992), 17, 20. Čedomir Popov, "Garašanin, Ilija,
} 
"jedan od najaktivnijih saradnika Srbije među Hrvatima na širenju revolucionarne propagande i podizanju ustanka" 20 , "taj stari saradnik iz Slavonskog Broda dobijao je od Garašanina poverljive političke zadatke u Hrvatskoj”. ${ }^{21}$ Andrijini kontakti s Garašaninom datiraju još s kraja 40-ih godina, kada je nakon poziva da se vrati iz Pariza natrag u Zagreb, Garašaninu poslao pet pisama ponudivši mu svoje političko-obavještajne usluge. ${ }^{22}$ Garašanin je u to vrijeme ustrojio tajnu mrežu agenata u slavenskim krajevima pod turskom vlašću s ciljem oslobođenja od Turske i pripajanja Srbiji. Iako tada suradnja nije bila realizirana, ostala je Andrijina trajna naklonost prema srpskoj Vladi i narodu te sada postaje veza hrvatskih narodnjaka sa srpskom Vladom Ilije Garašanina preko agenta Antonija Oreškovića. Korespondencija s Oreškovićem pokazuje da je Andrija bio uključen u Strossmayerove i Garašaninove političke planove kojima je krajnji cilj bio stvaranje južnoslavenske države zajedno sa Srbijom od područja koja su tada bila pod austrijskom i turskom upravom.

Antonije Orešković23 rođen je u Dvoru na Uni 7. siječnja 1829., a umro je u Beogradu 14. prosinca 1906. godine. Nakon završetka vojne akademije u Bečkome Novom Mjestu 1847. ostao je u austrijskoj vojsci, u službi u Vojnoj krajini, sve do 1862. s činom kapetana. Od 1858. održavao je tajnu vezu s Garašaninom. Namjeravao je, na njegov poziv, početkom lipnja 1862. napustiti vojnu službu podnoseći ostavku, no (prokazan austrijskim vlastima) morao je već u travnju prebjeći u Srbiju. Na poziv kneza Mihaila Obrenovića ${ }^{24}$ da svojim bogatim vojnim iskustvom pripremi Srbiju za oslobodilačke ratove i pomogne "da Srbija postane centar i predstavnik Jugoslovenstva", ${ }^{25}$ stupio je odmah u srpsku vojsku. Aktivno je radio na pridobivanju austrijskih časnika za prelazak u Srbiju. Organizirao je vrbovanja graničara i njihovo prebacivanje u Srbiju. U većim gradovima Vojne krajine stvoreni su tajni odbori za vrbovanje od kojih se po važnosti isticao onaj u Karlovcu, koji je uspio i prokrijumčariti oružje i municiju za Srbiju. ${ }^{26}$ Orešković je dodijeljen Garašaninu za specijalne vojne i političke poslove, bio je njegov glavni

\footnotetext{
državnik, političar (1812-1874)", u: Srpski biografski rečnik (dalje: SBR), sv. 2 (Novi Sad: Matica srpska, 2006), 616-624.

${ }^{20}$ Vasilije Krestić, Srpsko-hrvatski odnosi i jugoslovenska ideja 1860-1873 (Beograd: Narodna knjiga, 1983), 235.

${ }^{21}$ Jakšić, Vučković, Spoljna politika Srbije, 361, bilj. 172.

22 Maixner, A. T. Brlić u Francuskoj, 40.

${ }^{23}$ O javnome djelovanju Antonija Oreškovića vidi u: Jakšić, Vučković, Spoljna politika Srbije. Vojislav Vučković, "Nacionalno-revolucionarna akcija Srbije u Vojnoj granici", Zbornik Matice srpske 9 (1954).

${ }^{24}$ Mihailo Obrenović (1823. - 1868.), srpski knez u dva navrata, 1839. - 1842. i 1860. - 1868. Boravio je u emigraciji od 1842. do 1858. godine, najviše u Beču. U Srbiju se vratio početkom 1859. zajedno $s$ knezom Milošem, a na prijestolje je stupio nakon Miloševe smrti 1860. Ubijen je u atentatu u lipnju 1868. godine.

${ }^{25}$ Antonije Orešković, Malo više svetlosti povodom brošure "Knjaz Mihailo i zajednička radnja balkanskih naroda" (Beograd: Štamparija Svetozara Nikolića, 1895), 29.

${ }^{26}$ Više o tajnim odborima i članovima vidi u: Vučković, "Nacionalno-revolucionarna akcija Srbije", 8.
} 
operativac i realizator vojnoobavještajnih aktivnosti. Koristio ga je za povjerljive poslove, osobito u Hrvatskoj, Vojnoj krajini i Bosni, a preko njega je od početka 1863. išla i Garašaninova veza s mađarskom emigracijom. Održavanje tajne veze s mađarskom emigracijom povjereno mu je kako ne bi došlo do kompromitacije srpske Vlade. Oreškovićev zadatak bio je nastaviti rad s mrežom agenata ${ }^{27} \mathrm{u}$ Vojnoj krajini i u Hrvatskoj te vršiti pripreme za buduću akciju u Bosni za koju se čekalo na povoljne međunarodne prilike. Ponesen jugoslavenskom idejom, težio je stvaranju samostalne države "koja bi pod imenom Jugoslovenska Kraljevina obuhvatala sve Srbe i Hrvate, i to ne samo austrijske nego i one turske carevine." 28 Međutim, da Srbi i Hrvati ne budu jedno, "staraju se", smatra Orešković, "plaćeni trubači koji pod firmom žarkog rodoljublja po notama pruženim iz Beča ili Pešte trube melodije koje laskaju plemenskoj sujeti. Dogod su zvuci tih trubača kadri da nadraže naše osećaje, badava će ih razbor žigosati kao pakla mamce, koji smeraju da nas održe u ropstvu." ${ }^{29}$ A na oslobađanju slavenskih plemena, odnosno naroda, od ropstva požrtvovno je radila Rusija ${ }^{30}$ i kada Slaveni shvate da protiv "sile ujedinjene nemštine ne mogu ostvariti svoje plemenske snove, oni će [...] tražiti svoje spasenje u zagrljaju i naručju ruskom." ${ }^{31}$ Orešković Srbiju vidi kao jugoslavenski Pijemont, "kao što geografski stoji u centru Jugoslovenstva treba da bude i centar jugoslovenskih težnji." ${ }^{32}$ Prva etapa u stvaranju te nezavisne jugoslavenske države trebalo je biti izazivanje ustanka u Bosni i njezino oslobađanje od turske vlasti. Godinama je pripremao taj ustanak. Izradio je planove za podizanje bune 1861., 1863., 1865. i 1867. godine. U ostvarenju toga cilja, po Garašaninovu nalogu, uspostavio je veze sa Strossmayerom, mađarskom emigracijom, austrijskim časnicima slavenskoga porijekla na službi u Vojnoj krajini i s nekoliko bosanskih begova. Preko Oreškovića je u kolovozu 1866. godine dobiveno obećanje biskupa Strossmayera da će pomagati akciju Srbije prema Bosni, a u travnju 1867. postignut je i kratkotrajni sporazum o zajedničkoj akciji između Strossmayera i kneza Mihaila na stvaranju nezavisne južnoslavenske države. Autor toga sporazuma bio je Orešković. U to vrijeme, 1866. i 1867. godine, djelovao je kao posrednik u pregovorima između srpske Vlade i Narodne stranke. Nakon prijeloma u političkome držanju kneza Mihaila i napuštanja dotadašnjega političkog smjera te smjene Garašanina s pozicije pred-

\footnotetext{
${ }^{27}$ Oreškovićevu tajnu mrežu agenata neko je vrijeme financirala i Italija osiguravajući si saveznike u slučaju rata s Austrijom. Orešković je uvjerio talijansku stranu u presudnu ulogu Vojne krajine u tome sukobu. Tražio je od Italije novčana sredstva za održavanje jake ogranizacije koja će mu omogućiti da spriječi odlazak graničara na talijanski front. U rujnu 1864. godine izradio je za Italiju Memoar o ulozi Vojne krajine u ratu između Italije i Austrije. Predlagao je da se istovremeno i u Ugarskoj i u Vojnoj krajini podigne ustanak, a da potom u rat uđe i Italija. Usp. Krestić, Srpsko-hrvatski odnosi, 237-238.

28 Orešković, Malo više svetlosti, 15.

29 Orešković, Malo više svetlosti, 18.

30 Usp. Orešković, Malo više svetlosti, 20.

31 Orešković, Malo više svetlosti, 38.

32 Orešković, Malo više svetlosti, 19.
} 
sjednika Vlade i ministra vanjskih poslova, Orešković je udaljen od političkih poslova pa su i veze s Vojnom krajinom i Hrvatskom bile oslabljene. No, ponesen idejom zajedničke radnje, i dalje je održavao veze sa Strossmayerom i neumorno radio na stvaranju mogućnosti podizanja ustanka u Bosni i sudjelovanja Hrvata u tim oslobodilačkim akcijama. Nakon ubojstva kneza Mihaila odgurnut od namjesnika ${ }^{33}$ počeo je raditi i na pomirenju između Hrvata i Mađara. Na njega je, od strane namjesnika Jovana Ristića, pala i sumnja da je "Kalajev agent" ${ }^{34}$ Uoči Srpsko-turskih ratova Oreškoviću je 1875. godine povjerena misija kod Strossmayera da ispita raspoloženje Hrvata za zajedničko pomaganje bosanskoga ustanka. Sudjelovao je u Srpsko-turskim ratovima 1876.-1878. i dobio odlikovanje. Unatoč vojnim zaslugama kralj Milan Obrenović nije ga unaprijedio u generala, nego ga je 1888. umirovio. Umro je 1906. u Beogradu.

\section{Političke prilike u pedesetim i šezdesetim godinama 19. stoljeća}

\section{Srpska politička misao u 19. stoljeću}

Sredinom 19. stoljeća Srbija je bila autonomna kneževina ${ }^{35}$ u sklopu Osmanskoga Carstva. U drugoj polovici 19. stoljeća politički se formirala, imala je ideologiju

\footnotetext{
${ }_{33}$ Tročlano namjesništvo: Jovan Ristić, Milivoje Blaznavac i Jovan Gavrilović, koje je obnašalo vlast u ime maloljetnoga kneza Milana, od 1868. do 1872. godine.

${ }^{34}$ Vučković, "Nacionalno-revolucionarna akcija Srbije", 18. Benjámin Kállay (1839. - 1903.), mađarski diplomat i političar. Bio je austro-ugarski generalni konzul u Beogradu (1868. - 1875.). U razdoblju od 1882. do 1903. godine obnašao je dužnost austro-ugarskoga ministra financija i upravitelja Bosne i Hercegovine.

${ }^{35}$ Početci autonomije Srbije sežu u 1815. godinu u vrijeme Drugoga srpskog ustanka. Konačno ju je dobila 1830., a na Berlinskome kongresu 1878. priznata joj je nezavisnost i stekla je međunarodno priznanje. Kneževina Srbija postojala je do 1882. kada je uspostavljena Kraljevina Srbija. U tome razdoblju od 1815. do 1882. godine Kneževinom su vladale dvije srpske vladarske obitelji: Obrenovići (1815. 1842. i 1858. - 1882.) i Karađorđevići (1842. - 1858.). Miloš Obrenović, osnivač Kneževine Srbije, dugo je izgrađivao svoju apsolutističku vlast koja je, nakon niza pobuna, ograničena 1838. godine takozvanim Turskim ustavom nakon kojega je knez Miloš 1839. abdicirao i napustio Srbiju. Ustavom je formiran Državni savjet Kneževine Srbije čije je članove postavljala ili potvrđivala turska Vlada, a čime je ograničena kneževa samovolja. Kneza Miloša naslijedio je njegov mlađi sin Mihailo Obrenović. Vladao je tri godine, sve do 1842. kada je zbačen nakon bune te je bio prisiljen napustiti Srbiju. Tada dolazi do smjene dinastije, a za novoga srpskog kneza izabran je Aleksandar Karađorđević, sin vođe Prvoga srpskog ustanka Karađorđa. Vladavina kneza Aleksandra Karađorđevića (1842. - 1858.) period je vlade ustavobranitelja, kako su nazivani branitelji ustavnoga poretka i protivnici kneževe samovolje kao i težnje za neograničenom vlašću. On je s ustavobraniteljima dijelio vlast u Srbiji do kraja 1858. godine. Knez Aleksandar sve se češće ponašao kao samostalan politički čimbenik te je razdoblje vlade ustavobranitelja završeno sukobom između kneza i Državnoga savjeta, što je dovelo do svrgavanja kneza Aleksandra i dinastije Karađorđević te vraćanja kneza Miloša i dinastije Obrenović. Nakon njegove kratkotrajne druge vladavine, od 1858. do 1860. godine, na prijestolje 1860. po drugi put dolazi knez Mihailo. Nakon Mihailova ubojstva 1868. vlast je, u ime maloljetnoga kneza Milana, obnašalo tročlano namjesništvo u sastavu: Milivoje Blaznavac, Jovan Ristić i Jovan Gavrilović. No, glavnu riječ imali su Blaznavac i Ristić. Knez Milan preuzeo je vlast 1872., a 1882. godine postao prvi srpski kralj. Vladimir Stojančević et al., Istorija srpskog naroda, knj. V-1: Od Prvog ustanka do Berlinskog kongresa 1804-1878 (Beograd: Srpska književna zadruga, 1981), 100-135, 251-301, 332-341.
} 
i program te političku koncepciju u kojoj se razmišljalo o njezinoj budućnosti. Najveći politički ideolog i jedan od najsposobnijih i najmoćnijih ljudi svojega vremena u Srbiji bio je Ilija Garašanin. Garašanin je glavni organizator tajne političke djelatnosti Kneževine Srbije prema susjednim nesrpskim zemljama sredinom 19. stoljeća. Tajni spis Načertanije, ${ }^{36}$ plan teritorijalnoga proširenja Srbije koji je sastavio 1844. godine, uzeo je kao službeni program, temelj srpske politike i osobno je sve vrijeme dok je bio na vlasti radio na njegovome ostvarivanju. Srpska politika težila je na ruševinama Osmanskoga Carstva uspostaviti novo srpsko carstvo, što bi i ostali Južni Slaveni trebali "s radostiju primiti". ${ }^{37}$ Naime, uvjeren u skori raspad Osmanskoga Carstva i prestanak turske uprave nad južnoslavenskim narodima, Garašanin je Srbiji namijenio povijesnu misiju obnove i proširenja Dušanova Carstva. Uspostavu toga carstva povezao je s potrebom proširenja srpske države koja će teritorijalno obuhvatiti sve krajeve u kojima ima Srba, ${ }^{38}$ a obrazloženje je našao u starome povijesnom pravu Srba da obnove svoje srednjovjekovno Dušanovo Carstvo, ali ne samo u opsegu koliko je bilo, nego u razmjerima do kojih bi se proširilo da nije bilo osmanlijskoga prodora. ${ }^{39}$

\footnotetext{
${ }_{36}$ Načertanije, velikosrpski programski spis, tajni spis srpske nacionalne i vanjske politike koji je 1844 . godine sastavio Ilija Garašanin, u to vrijeme ministar unutarnjih poslova u Vladi kneza Aleksandra Karađorđevića. Šira javnost ništa nije znala o tome programu sve do 1906. kada je postao dostupan zahvaljujući Milenku Vukićeviću koji ga je tada prvi puta u cijelosti objavio u beogradskome Delu. Taj ključni spis srpske političke misli 19. stoljeća i temeljni nacrt koji će srpska politika slijediti i nakon Garašanina izvorno je nastao na poticaj grofa Czartoryskoga, vođe poljske emigracije u Parizu, a idejno polazište imao je u južnoslavenskome planu Františeka Zacha, koji je predviđao stvaranje velike južnoslavenske države na razvalinama dvaju carstava. Preuređujući taj, slavenofilskim duhom nadahnut, Zachov nacrt, Garašanin je učinio odmak i pretvorio ga u velikosrpski program okupljanja svih "srpskih naroda" u jednu državnu zajednicu. Da bi se to ostvarilo, već je u samome Načertaniju predviđena mreža povjerenika koji bi slali obavijesti iz susjednih zemalja. Upravo su u Načertaniju postavljeni temelji čitave srpske propagande na Balkanu. Posebna pozornost posvećena je Bosni i Hercegovini, Crnoj Gori i sjevernoj Albaniji u kojima se, po Garašaninu, mogao ostvariti najveći utjecaj. Albanija i Crna Gora, prema Garašaninu, "imadu ključeve od vrata Bosne i Hercegovine i od samoga mora Adrijatičeskog". Stavovi i ideje iz Načertanija osnovica su svih velikosrpskih posezanja za tuđim teritorijima. Damir Agičić, Tajna politika Srbije u XIX. stoljeću (Zagreb: AGM, 1994), 17-26. Šimunić, "Načertanije"- Tajni spis, 5-28, $47-$ 53. Mirko Valentić, "Prva programska formulacija velikosrpske ideje", u: Izvori velikosrpske agresije, prir. Bože Čović (Zagreb: August Cesarec; Školska knjiga, 1991), 41-59. Načertanije je u cjelini objavljeno u: Izvori velikosrpske agresije, prir. B. Čović, 65-77. te u: Šimunić, "Načertanije" - Tajni spis, 91-108.

${ }^{37}$ Ilija Garašanin, Načertanije, u: Šimunić, "Načertanije" - Tajni spis, 94.

38 "čerta i temelj srpske politike, da se ona ne ograničava na sadašnje njene granice, no da teži sebi priljubiti sve narode srpske koji ju okružavaju." Garašanin, Načertanije, u: Šimunić, "Načertanije” - Tajni spis, 91. 39 "Srpska država koja je već srećno počela, no koja se rasprostirati i ojačati mora, ima svoj osnov i temelj tvrdi u carstvu srpskom 13-ga i 14-ga stoljetija i u bogatoj i slavnoj srpskoj istoriji. Po istoriji ovoj zna se da su srpski carevi počeli bili grčkom carstvu mah otimati i skoro bi mu konac učinili te bi tako na mesto propadšega istočno-rimskog carstva srbsko-slavensko carstvo postavili i ovo naknadili. Car Dušan silni primio je već grb carstva grčkog. Dolazak Turaka prekinuo je ovu promenu i preprečio je ovaj posao za dugo vreme, no sad, pošto je sila turska slomljena i uništena tako reći, treba da počne isti onaj duh dejstvovati, prava svoja na novo tražiti, i prekinuti posao na novo nastaviti. Ovaj temelj i ove osnove zidanja carstva srbskog valja dakle sad od razvalina i nasutima sve većma čistiti i osloboditi, na vidik izneti, i tako na ovako tverdom i stalnom istoričeskom fundamentu novo zidanje opet preduzeti i nastaviti. Črez to će ovo predprijatije u očima sviju naroda a i samih kabineta, neiskazanu važnost i viso-
} 
Odmah nakon sastavljanja Načertanija Garašanin je počeo s pripremama oko realizacije toga srpskog nacionalnog i vanjskopolitičkoga programa. Pokrenuo je nacionalnu političku propagandu i pripreme za podizanje ustanka protiv Turaka za oslobođenje Srba i Južnih Slavena od turske vlasti i za njihovo ujedinjenje u jednu državu. U Beogradu je srpska Vlada 1849. godine stvorila posebnu središnju tajnu organizaciju za srpsku političku propagandu kojom je rukovodio Garašanin. ${ }^{40}$ On je u slavenskim krajevima pod turskom vlašću ustrojio razgranatu obavještajnu mrežu tajnih agenata s krajnjim ciljem pripajanja tih teritorija Kneževini Srbiji. ${ }^{41}$ Agenti su upućivani u južnoslavenska područja s naputcima da mu šalju izvješća o svemu što su vidjeli i čuli. U tim krajevima uspostavljale su se veze s povjerljivim ljudima koji su pridobiveni za suradnju sa Srbijom, a u Srbiju su stizala izvješća o stanju, prilikama i raspoloženju stanovništva prema turskoj vlasti i prema Srbiji. Među prvim propagatorima i širiteljima srpske nacionalne misli bio je Matija Ban ${ }^{42}$ iz Dubrovnika. Uz njega Garašaninovi najbliži surad-

ku vrednost zadobiti; jer ćemo onda mi Srbi pred svet izići kao pravi naslednici velikih naših otaca koji ništa novo ne čine no svoju dedovinu ponavljaju. Naša dakle sadašnjost neće biti bez sojuza sa prošlošću, nego će ova činiti jedno zaviseće, sastavno i ustrojeno celo, i zato Srbstvo, njegova narodnost i njegov državni život stoji pod zaštitom svetog prava istoričeskog. Našem teženju ne može se prebaciti, da je ono nešto novo, neosnovano, da je ono revolucija i prevrat, nego svaki mora priznati da je ono politički potrebno, da je u prastarom vremenu osnovano i da koren svoj u pređašnjem državnom i narodnom životu Srba ima (...)." Garašanin, Načertanije, u: Šimunić, “Načertanije” - Tajni spis, 93.

40 Garašanin, Marinović, Ban i Kovačević sastavili su i detaljno razradili plan po kojemu će se raditi, a pod naslovom Ustav politične propagande imajući se voditi u zemljama Slaveno-turskim. Taj statut tajne organizacije političke propagande izradili su 1849. godine, a 1850. zamijenjen je novim, dijelom izmijenjenim, statutom čiji je autor Tomo Kovačević. U okvir djelatnosti Ustava ušla su ista područja koja obuhvaća Načertanije: Bosna, Hercegovina, Crna Gora, Južna Srbija, novopazarski Sandžak, Gornja Albanija, Jugozapadna Bugarska, Dalmacija i predjeli oko hrvatsko-slavonske granice. I u Statutu iz 1849. i u onome iz 1850. jasno je da Garašanin i njegovi suradnici Hrvate katolike smatraju "Srbima zapadnog veroispovedanja”. Isto tako i u Statutu iz 1850. stoji da je jedina dužnost katoličkih agenata u Bosni “iskorenjivati mrzost koja sada između Srba vostočnog i zapadnog veroispovedanija postoi” i izričito je navedeno da se katoličkim agentima "od plana ove politične propagande ništa neodkriva". Ustav politične propagande imajući se voditi u zemljama Slaveno-turskim u: Agičić, Tajna politika Srbije, 121-131.

${ }^{41}$ O strukturi, organizaciji i načinu rada agenture u prvome razdoblju njezina djelovanja vidi u: Agičić, Tajna politika Srbije, 72-104.

42 Matija Ban (1818. - 1903.), književnik i političar, rođen je u Petrovu Selu kod Dubrovnika. U Dubrovniku je završio osnovnu školu i gimnaziju i stupio u franjevački red, no ubrzo je napustio svećenički poziv. U Beograd je došao 1844. godine. Knez Aleksandar Karađorđević povjerio mu je odgoj svojih kćeri, a Garašanin ga je politički angažirao. Bio je među onima koji su provodili ideje Načertanija i jedan od nositelja tajne organizacije za srpsku političku propagandu. Kao tajni agent srpske Vlade, putujući Dalmacijom i boraveći u Dubrovniku, širio je srpsku propagandu. Bio je jedan od najistaknutijih zastupnika ideje o srpsko-katoličkome Dubrovniku. Godine 1860. pao je u nemilost srpske Vlade i ostao bez službe. U Beogradu je iste godine osnovao Odbor srpsko-bosanski kojemu je zadatak bio pripremiti ustanak u Bosni i Hercegovini s ciljem da je pripoji Srbiji, ali mu je knez Mihailo 1861. naredio da organizaciju raspusti. Preveo je s poljskoga i dopunio Pravila o četničkoj vojni 1848., službeni priručnik srpske Vlade za gerilsko ratovanje i u ratnim i mirnodopskim uvjetima. U književnosti se javio dramama na talijanskome jeziku. Zapaženiji je kao pisac četrnaest drama i tragaedija tematski vezanih uz slavensku, ponajviše srpsku povijest. Martin Kaminski, "Ban, Matija, pjesnik, dramatičar, političar i publicist (1818-1903)”, u: Hrvatski biografski leksikon, sv. 1 (Zagreb: Jugoslavenski leksikografski zavod “Miroslav Krleža”, 1983), 408-411. 
nici bili su Jovan Marinovićc ${ }^{43}$ iz Sarajeva, kao njegov pomoćnik u organizaciji i provođenju političke propagande, i Tomo Kovačević, ${ }^{44}$ bivši bosanski franjevac. Najintenzivnije djelovanje tajne organizacije bilo je u periodu od 1849. do 1851 . godine. Primjetno je slabljenje njezine djelatnosti u drugoj polovici 1850., a 1851. posve zamire. S povlačenjem Garašanina s političke pozornice i propaganda je svedena na najmanju mjeru. Tek kada je Garašanin 1858. vraćen na dužnost ministra unutarnjih poslova, živnula je i tajna politička djelatnost Srbije. Izradio je plan srpske političke akcije u Bosni, Plan po kome se u ovoj 1858. godini ima raditi, ${ }^{45}$ a u kojemu se osobita pozornost poklanjala akciji među graničarima u Vojnoj krajini. Početkom 1862. Garašanin je osnovao Srpski odbor za nacionalnu propagandu u susjednim zemljama. Rad je obavljan organizirano, pod vodstvom i nadzorom srpske Vlade. Tijekom četrdesetih, pedesetih i šezdesetih godina 19. stoljeća mnogi političari, državni službenici i javni djelatnici iz Srbije, Bosne i Hercegovine, Bugarske i Habsburške Monarhije bili su uključeni u različite tajne akcije Srbije. Istu je obavještajnu mrežu Garašanin angažirao i 1867. u pripremama protuturskoga ustanka u Bosni, a čiji je program izradio Antonije Orešković s ciljem stvaranja velike nezavisne južnoslavenske države.

\section{Hrvati i Srbija za vlade kneza Mihaila 1860.-1868. Suradnja i zajednički program stvaranja južnoslavenske države 1866. - 1868.}

Dolazak kneza Miloša Obrenovića na vlast 1858. godine, nakon svrgavanja Aleksandra Karađorđevića na Svetoandrejskoj skupštini, a potom 1860. i njegova nasljednika kneza Mihaila, smatrao se uvodom u aktivniju i širu političku akciju Srbije koja je trebala dovesti do oslobođenja od turske vlasti i ujedinjenja. Vanjska politika kneza Mihaila bila je vezana za istočno pitanje. Čitavu svoju politiku Srbija je usmjerila prema Bosni i Hercegovini. Pripremala se za akciju i bila je

\footnotetext{
43 Jovan Marinović (1821. - 1893.), srpski političar i diplomat, činovnik Ministarstva unutarnjih poslova Kneževine Srbije i blizak Garašaninov suradnik. Kao pomoćnik poglavara organizacije za političku propagandu Ilije Garašanina nadzirao je cijelu mrežu srpske propagande. Bio je stalni savjetnik kneza Mihaila za vanjsku politiku i u njegovoj je pratnji putovao u Carigrad 1867. Od 1873. do 1874. godine obnašao je dužnost predsjednika Vlade Kneževine Srbije i ministra vanjskih poslova u Vladi kneza Milana Obrenovića. Radomir J. Popović, "Marinović, Jovan, državnik, političar, diplomata (1821-1893)”, u: SBR, sv. 6 (Novi Sad: Matica srpska, 2014), 86-88.

44 Tomo Kovačević (1820. - 1863.), Garašaninov povjerenik za propagandni rad u Bosni i Hercegovini. Boravio je u Srbiji od 1843. godine. Prihvatio je srpsku nacionalnu ideju i postao jedan od najpovjerljivijih suradnika Ilije Garašanina. Momir Samardžić, "Kovačević, Tomo, franjevac, poverenik srpske vlade (1820-1863)", u: SBR, sv. 5 (Novi Sad: Matica srpska, 2011), 146-147.

45 Plan se odnosio na tajnu djelatnost u Bosni. U ovome planu, kao i u Načertaniju, Garašaninova politička misao inspirirala se postavkom da se Srbija mora proširiti. Srpskim agentima dane su upute da najenergičnije rade na suzbijanju austrijske propagande i njezina utjecaja na tamošnje katolike. Isto tako preporučeno im je da rade protiv hrvatskih težnji i suprostavljaju se hrvatskomu utjecaju u Bosni kao produženoj ruci austrijskih interesa. Usp. Krestić, Srpsko-hrvatski odnosi, 17 i Agičić, Tajna politika Srbije, 109.
} 
odlučna pripojiti je sebi u povoljnim međunarodnim okolnostima. Veliku pozornost posvećivala je nacionalnoj propagandi i stvaranju tajnih odbora potrebnih za dizanje općega ustanka u Osmanskome Carstvu, jačanju na vojničkome polju i diplomatskim misijama kao dijelovima općih priprema za oslobodilačku akciju. Pitanje raspada Osmanskoga Carstva bilo je, pak, od širega političkog značenja. Za njegovo rješenje bili su zainteresirani ne samo Srbija i balkanski narodi, nego i velike sile koje su u istočnome pitanju imale odlučujuću riječ pa je i oslobodilačka akcija Srbije bila povezana s političkim planovima velikih sila. Svoje planove morala je usklađivati s politikom onih sila koje su joj u određenome trenutku iz vlastitih interesa bile spremne pružiti podršku. Paralelno s tim Srbija je razvila veliku aktivnost u stvaranju saveza balkanskih država i naroda. Povezala se s Crnom Gorom i Bugarskom, a savez je sklopila i s Rumunjskom i Grčkom. Tu se nametalo pitanje suradnje s Hrvatskom, koja bi s Vojnom krajinom u oslobodilačkoj akciji trebala odigrati važnu ulogu. Knez Mihailo u svemu je tome nastojao Srbiji osigurati vodeću ulogu kao središta oko kojega će se okupljati ne samo Srbi, nego i svi Južni Slaveni. Mihailo i Garašanin najvećega su protivnika srpskih interesa i glavnoga protivnika oslobodilačkih težnji balkanskih naroda vidjeli u Austriji i namjeravali su iskoristiti krizu u koju je zapala. ${ }^{46}$

Nakon sloma apsolutizma u Habsburškoj Monarhiji se tijekom šezdestih godina 19. stoljeća vodila rasprava i borba oko državnoga preuređenja između pristaša centralizma, federalizma i dualizma. $U$ to vrijeme gotovo svi političari budućnost Hrvatske vidjeli su u okvirima Monarhije. Razlike u političkim stavovima nastajale su povodom problema njezina preuređenja. Narodna stranka na čelu s biskupom Strossmayerom aktivno je sudjelovala u rješavanju toga državnog pitanja zalažući se za preuređenje Monarhije na federalističkim osnovama. U težnji da ostvare federalizam Narodna stranka surađivala je s federalističkim krugovima u Beču, a osobito s Česima i Poljacima koji su imali iste ciljeve. Sve do austrijskoga poraza od Pruske kod Sadove 1866. godine nije gubila nadu u federativno preuređenje Monarhije. Politička koncepcija unionista bila je što čvršćom državnopravnom vezom povezati Hrvatsku s Ugarskom, a što se moglo ostvariti samo u dualistički uređenoj Monarhiji te su sve snage usmjerili u tome smjeru. Šezdesetih godina 19. stoljeća bili su uspostavljeni bliski politički odnosi Srbije i Hrvata. Suradnja je uspostavljena u vrijeme nastajanja Hrvatsko-ugarske nagodbe.

U lipnju 1866. godine došlo je do Austrijsko-pruskoga rata. Nakon poraza od Pruske kod Sadove Monarhija je bila u temeljima poljuljana pa je i njezin opstanak doveden u pitanje. Jake struje unutar Monarhije htjele su njezino preuređenje prema dualističkome načelu. Slavenski narodi opredijeliili su se za reformu Mo-

$\overline{46}$ O političkim prilikama u Kneževini Srbiji i njezinoj vanjskoj politici za vrijeme vladavine kneza Mihaila Obrenovića vidi u: Jakšić, Vučković, Spoljna politika Srbije. Krestić, Srpsko-hrvatski odnosi. Slobodan Jovanović, Druga vlada Miloša i Mihaila (1858-1868) (Beograd: Izdavačka knjižara Gece Kona, 1923). 
narhije na federalističkim osnovama. U Beču je u kolovozu 1866. održan susret vodećih predstavnika Poljaka, Čeha i Hrvata uz sudjelovanje biskupa Strossmayera i Matije Mrazovića. Njihov prijedlog o federalnoj organizaciji Monarhije car nije uzeo u obzir. Javno je Narodna stranka pregovarala s Mađarima i Bečom. Kako pregovori s Mađarima nisu uspjeli, u prosincu 1866. okrenula se izravnim pregovorima s Bečom. Međutim, Franjo Josip I. već je bio prihvatio ideju dualizma pa je hrvatsku delegaciju na čelu sa Strossmayerom hladno primio. Potom je u siječnju 1867. raspustio Hrvatski sabor. Kada je tako porazom Austrije u ratu s Pruskom sasvim prevladala ideja dualizma, propali su i svi planovi i nade narodnjaka predvođenih biskupom Strossmayerom o preuređenju Monarhije na federalističkim osnovama na kojim je bila izgrađena čitava njihova politika. Prihvaćanje dualizma utjecalo je na Narodnu stranku da napusti svoje ranije stavove te je od tada budućnost Hrvatske vidjela izvan Habsburške Monarhije. Narodna stranka tada se povezala sa srpskom Vladom. Strossmayer je u ime stranke krajem kolovoza 1866. pristao da Hrvatska zajedno sa Srbijom radi na osnivanju zajedničke južnoslavenske države koja neće biti ovisna ni o Habsburškoj Monarhiji ni o Osmanskome Carstvu. Suradnja i ugovor sa Srbijom ostvarivani su u trenutcima kada su se polagali temelji za konačni preustroj Monarhije, u trenutcima koji su dugoročno odredili položaj Hrvatske. Za kontakte sa Strossmayerom i narodnjacima Garašanin je koristio svoga agenta, bivšega austrijskog časnika Antonija Oreškovića. Oreškovićeva veza s Hrvatima bio je Andrija Torkvat Brlić. Sporazumom iz travnja 1867. godine stvorili su tajni politički program o zajedničkoj južnoslavenskoj politici. Istovremeno je u Beogradu izrađen ratni plan protiv Osmanskoga Carstva i o podizanju ustanka u Bosni. I plan i program sastavio je Antonije Orešković, no konačnu redakciju dao je Ilija Garašanin. Akcija u Bosni predviđena je za ljeto 1867. godine. Oslobođenje Bosne trebala je biti prva etapa $\mathrm{k}$ daljnjemu oslobođenju Južnih Slavena i stvaranju zajedničke države. Programom se Narodna stranka obvezala da će svoju politiku u Monarhiji voditi tako da će izbjegavati savez s Ugarskom i Bečom kako bi u budućnosti imala slobodne ruke. U međuvremenu je Srbija uspjela diplomatskim putem isposlovati da joj Turci u travnju 1867. ustupe gradove koje su držali. A kada je grof Gyula Andrássy ${ }^{47}$ u kolovozu 1867., na sastanku u Ivanki, Mihailu obećao Bosnu, knez je izvršio veliki zaokret u vanjskoj politici i potpuno iznevjerio ugovor koji su sklopile Narodna stranka i srpska Vlada. Narodna stranka je, pak, sve svoje snage usmjerila na sporazum i suradnju sa Srbijom i pri tome zanemarila ostale frontove očekujući da će se Srbija držati ugovora o zajedničkoj akciji. Stoga u odlučnome trenutku, kada su se održavali izbori za Hrvatski sabor koji je trebao sklopiti Nagodbu s Mađarima, Narodna stranka nije organizirala opoziciju protiv unionista. Doživjela je težak poraz na izborima u studenome i prosincu 1867. godine. Novi Hrvatski sabor

47 Gyula Andrássy (1823. - 1890.), prvi ugarski ministar-predsjednik u Austro-Ugarskoj (1867. - 1871.) te austrougarski ministar vanjskih poslova (1871. - 1879.). 
sazvan je u siječnju 1868. s ogromnom unionističkom većinom. Sudbina Hrvatske bila je određena sve do raspada Monarhije. ${ }^{48}$

\section{Pisma Antonija Oreškovića Andriji Torkvatu Brliću kao povijesni izvor}

U Arhivu obitelji Brlić sačuvano je 39 pisama Antonija Oreškovića upućenih Andriji Torkvatu Brliću u vremenskome razdoblju od 1857. do 1868. godine. Čuvaju se pod inventarnim brojem 21, svežnjići 9, 10 i 11. Osim dva koja su djelomično izrezana, pisma su dobro očuvana. Na pojedinima je Andrija Torkvat Brlić ukratko skicirao svoj odgovor Oreškoviću. Najvećim su dijelom pisma pisana iz Beograda, a potom iz Dubice, Rujevca, Petrinje i Šapca. Pisana su latinicom i ćirilicom, na hrvatskome i njemačkome jeziku. Orešković se potpisivao punim imenom i prezimenom, no koristio je i pseudonime Sava Savić, Gruić, Vuica Srećković, Golobradić. Zbog cenzure je mijenjao rukopis. Koristio je i lozinke i šifre. Pisma su šifrirana brojevima. Sačuvan je i ključ za dešifriranje.

Pisma su već korištena u historiografiji. Do sada je objavljeno šest pisama, a objavio ih je Mato Artuković. ${ }^{49} \mathrm{U}$ svojim istraživanjima koristili su ih i Vasilije Krestić, ${ }^{50}$ Grgur Jakšić i Vojislav Vučković. ${ }^{11}$ Poznanstvo i veza Antonija Oreškovića, agenta srpske vlade, i Andrije Torkvata Brlića, posrednika između hrvatskih narodnjaka i Oreškovića, te pisma koje je Orešković, kao čovjek upućen u aktualna zbivanja, izravni sudionik i pregovarač, uputio Brliću važna su za rekonstrukciju odnosa Narodne stranke s Kneževinom Srbijom i posljedično tomu i za razumijevanje nepovoljnoga ishoda Nagodbe za hrvatsku stranu. Budući da je u ključnim trenutcima, kada su se polagali trajni temelji za konačni preustroj Habsburške Monarhije, Narodna stranka svoje težište interesa stavila izvan granica Monarhije, na stvaranje južnoslavenske države u suradnji sa Srbijom, tako je sve svoje karte stavila samo na jednu stranu potpuno zanemarivši ostale fronte očekujući da će se Srbija držati ugovorenoga programa. Oreškovićeva pisma važna su i za ocjenu politike srpske Vlade prema Hrvatima i Oreškovićeve uloge kao posrednika između jedne i druge strane. Osim važnoga izvora za poznavanje odnosa Narodne stranke i Srbije u razdoblju od 1866. do 1868. godine, Oreškovićeva pisma, s obzirom da su nastala u vrijeme i vrlo aktivnoga rada srpske nacionalne

\footnotetext{
${ }^{48}$ O političkim prilikama u Habsburškoj Monarhiji 60-ih godina 19. stoljeća i sudbonosnim događajima koji su prethodili sklapanju Nagodbe vidi u: Ciliga, Slom politike Narodne stranke. Petar Korunić, "Jugoslavenska ideja u hrvatskoj politici 1866-1868., Zbornik Zavoda za povijesne znanosti Istraživačkog centra JAZU 11 (1981): 1-107. Jaroslav Šidak, Studije iz hrvatske povijest XIX stoljeća (Zagreb: Grafički zavod Hrvatske, 1973).

${ }^{49}$ Mato Artuković, "Pisma Antonija Oreškovića”, Vijesti: godišnjak Muzeja Brodskog Posavlja 8 (1994): 131-138.

${ }^{50}$ Vasilije Krestić, Hrvatsko-ugarska nagodba 1868. godine (Beograd: Srpska akademija nauka i umetnosti, 1969) i Krestić, Srpsko-hrvatski odnosi.

${ }^{51}$ Jakšić, Vučković, Spoljna politika Srbije.
} 
propagande, daju informacije i o razgranatoj obavještajnoj mreži tajnih agenata, čiji je ključan član bio Orešković kao središnja ličnost u radu s graničarima i organizator njezina djelovanja i ilegalnih akcija. Iz pisama doznajemo i poneku sitnu pojedinost iz privatnoga života Andrije Torkvata Brlića i Antonija Oreškovića.

Iz pisama je također vidljivo prisno i "staro prijateljstvo" 52 koje je povezivalo Oreškovića s Andrijom i njegovom obitelji. Pisma otkrivaju da je Andrija često pobolijevao i boravio u toplicama. ${ }^{53}$ Orešković često kroz cijelu prepisku izražava svoju zabrinutost za njegovo zdravlje, osobito ako duže vremena ne čuje ništa od njega; moli ga da mu piše kako je i da se čuva. Pita za Andrijinu suprugu Faniku, za Nacu ${ }^{54}$ i za vinograde koje posjeduju. Brlići su se, među ostalim, bavili i proizvodnjom vina, a iz Oreškovićevih pisama vidljivo je da Andrija nije propuštao priliku da ih pošalje i svojemu prijatelju. Orešković obećava da će mu odgovoriti na njegov poziv na berbu i s veseljem ga u Brodu pohoditi. ${ }^{55} \mathrm{Iz}$ pisama se saznaje da Antonije ima sestru Ninu za koju piše da će doći u Brod i moli Andriju da je primi i da odsjedne u njegovoj kući, u istoj sobici u kojoj je i on boravio kada je bio kod njega. ${ }^{56} \mathrm{No}$, Antonije nije propuštao ni priliku da Andrijinu bratu Ignjatu udijeli političke savjete pa piše Andriji neka mu poruči da ga on moli, "kao brata i rodjaka",57 "neka bude pametan i neka se okani dok je još vremena unionista i Madjaorsaga." 58

Orešković u svojim sjećanjima, Malo više svetlosti, piše o svojemu doprinosu u buni u Bosanskoj krajini i Posavini 1858. godine, spominje Brodski odbor i kako je na kraju, pošto su austrijske vlasti posumnjale u njega, bio suđen, ali ne i osuđen, nego je završilo na tome da je premješten u unutrašnjost. ${ }^{59}$ I njegova pisma Brliću ujedno su izvor iz kojega se vidi da je imao znatnu ulogu u organizaciji ustanka u Bosanaskoj Posavini 1858. godine. U pismima Brliću 1858. traži pomoć i piše: "šalji ako imaš, sila je [...] Mora se sada valjano napredovati, jerbo mogli bi prije postradati, nego smo kadri što početi. Jako, jako sam potreban!! Stvar jako dobro napreduje. Pripravno na daleko sve čeka, ali fali što najviše treba." ${ }^{60}$ Nezadovoljan je jer "izvan dviju stotina koje mi je onaj Gospodin na koga si me ti adresiro, dan prije, kroz jednog čoveka odpravio, ne dobi tamo nikakve pomoći. Tersi de se,

\footnotetext{
${ }^{52}$ Hrvatska (dalje: HR) - Arhiv obitelji Brlić, Slavonski Brod (dalje: AOB), Pismo Antonija Oreškovića Andriji Torkvatu Brliću (dalje: Pisma A. Oreškovića) od 21. rujna 1867., kut. 21, sv. 10. (Prijepis Ivan Brlić).

${ }^{53}$ HR-AOB, Pismo A. Oreškovića od 28. travnja 1857., kut. 21, sv. 10. (Prijepis Ivan Brlić).

${ }^{54}$ Andrijin brat Ignjat Brlić.

${ }^{55}$ HR-AOB, Pismo A. Oreškovića od 17. rujna 1860., kut. 21, sv. 10 (Prijepis Ivan Brlić).

${ }^{56}$ HR-AOB, Pismo A. Oreškovića od 25. svibnja 1862.

${ }^{57}$ HR-AOB, Pismo A. Oreškovića od 17/29. kolovoza 1867.

${ }^{58}$ HR-AOB, Pismo A. Oreškovića od 11/23. srpnja 1867.

59 Usp. Orešković, Malo više svetlosti, 23-26.

${ }^{60}$ HR-AOB, Pismo A. Oreškovića od 5. svibnja 1858., kut. 21, sv. 10. (Prijepis Ivan Brlić).
} 
brez pomoći nemore knjiga zaufano izići." ${ }^{1}$ Bila je to jedna od lozinki ("knjiga izići”) koje su Orešković i Brlić upotrebljavali u svojoj korespondenciji, a ovdje je označavala početak akcije. ${ }^{62}$ Orešković će se i devet godina poslije, u pismu Brliću iz prosinca 1867. godine, referirati na taj ustanak i podsjetiti da je on taj koji je tada "pobunio Bosnu". 63

Od početka 1862. u Srbiji je razmatrana mogućnost izbijanja rata između Srbije i Osmanskoga Carstva te ustanka u Bosni i Hercegovini. Izrađeno je nekoliko vojnih planova podnesenih srpskoj Vladi. Jedan od planova izradio je i srpskoj Vladi poslao i Orešković. Njegova velika aktivnost na tome polju izazvala je sumnje austrijskih vlasti te se našao u nezgodnome položaju. ${ }^{64} \mathrm{U}$ to vrijeme, dva mjeseca prije nego je prebjegao u Srbiju, piše Andriji da je premješten u unutrašnjost i traži njegovo mišljenje što da učini: "soll ich allem entsagen und gehen, oder soll ich meine Charge quittieren." ${ }^{55}$ Sudeći po sljedećemu Oreškovićevu pismu, Andrija je u svome odgovoru spominjao unapređenje čim mu Orešković piše: "nasmija se malo tvojem svetovanjem. Meni se čini da ti misliš da ja idem u Regulaši da postanem Majorem, a ne znaš da ja tamo se odpravljam da dođem pod pazku. [...] a Majorom postat nikada neću." ${ }^{\prime 6} \mathrm{U}$ istome pismu Orešković piše da ne želi ni "generalie švabske, a najvolio bi da nas vrag, to jest mene i Švabu, jedanput rastavit more". ${ }^{67}$ Kaže da mu nije stalo do njega samoga, nego "za stvar" jer kada on ode, "sve će duhom klonuti". Javlja mu da je poslao pouzdanoga čovjeka u Beograd Iliji Garašaninu od kojega očekuje uputu što učiniti, a Andriji šalje trgovca iz Dubice, Milu Ervačanina, koji bi potom trebao otići u Đakovo "da i tamo sondira što se misli i što će mi se poručiti, da idem ili da ostajem. Ele ako mi i Štrosmajer poruči da idem, ja ode!" 68 Kako je Austrija dobrim dijelom bila upoznata s radom tajnih odbora u Vojnoj krajini, s planovima o dizanju ustanka, mrežom krijumčara oružja i municije, poduzimala je mjere kako bi pravovremeno zaustavila ilegalne akcije pokretane iz Beograda. ${ }^{69}$ Sve oficire u čiju je odanost sumnjala rješavala je zapovjednih položaja ili premještala u druge krajeve. $\mathrm{O}$ tome i Orešković piše Brliću 1862. godine: "ovde nas ružno raščeraše. 21 oficira

\footnotetext{
${ }^{61}$ HR-AOB, Pismo A. Oreškovića od 16. svibnja 1858.

${ }_{62}$ Iz sačuvanoga ključa za dešifriranje i popisa lozinki izdanje knjige=akcija; I Brlić tako u skici svoga odgovora na poleđini Oreškovićeva pisma od 28. prosinca 1860. koristi istu lozinku i piše da će ići u Zemun da ondje o onom izdanju knjige poso svršim. Ako su nakani kože dati, bit će pšenice. Ja se u tebe uzdam i glavu moju ulažem. Pri čemu upotrebljava i lozinke koža=novčana sredstva, pšenica=vojnici.

${ }^{63}$ HR-AOB, Pismo A. Oreškovića od 18/30. prosinca 1867., kut. 21., sv. 10. (Prijepis Ivan Brlić).

${ }^{64}$ Usp. Jakšić, Vučković, Spoljna politika Srbije, 130-131. i Vučković, "Nacionalno-revolucionarna akcija Srbije", 7.

${ }^{65}$ HR-AOB, Pismo A. Oreškovića od 21. veljače 1862., kut. 21., sv. 10. (Prijepis pisma Ivan Brlić).

${ }^{66}$ HR-AOB, Pismo A. Oreškovića od 3. ožujka 1862.

${ }^{67}$ HR-AOB, Pismo A. Oreškovića od 3. ožujka 1862.

${ }^{68}$ HR-AOB, Pismo A. Oreškovića od 3. ožujka 1862.

${ }^{69}$ Krestić, Srpsko-hrvatski odnosi, 236.
} 
već od Regimente premetnuše." ${ }^{70}$ ovo vrijeme Garašanin, bojeći se austrijskoga utjecaja u Bosni, nije vjerovao Hrvatima ni biskupu Strossmayeru jer, pisao je on, "premda oni rade u ime hrvatskog naroda, opet to ništa drugo ne znači nego raditi za Austriju kojoj Hrvatska u svemu prinadleži." ${ }^{\prime 1}$ Biskupa je smatrao austrijskim agentom i plaćenikom koji je na čelu austrijske propagande u Bosni. Sluteći da su mnogi graničari pod njegovim utjecajem, zahtijevao je oprez pri uspostavljanju suradnje s njima i tražio da se zadobiju oni koji su odani i spremni služiti srpskoj državnoj ideji obećavajući im da će im Srbija osigurati budućnost. ${ }^{72}$ O nepovjerenju prema biskupu Strossmayeru piše i Orešković Brliću: "Ovde o njemu jako sumnjaju budući da on u zadnje vreme znatne sume novaca biškupu Frankoviću ${ }^{73}$ koji po Bosnoj contra radi posla. Ja sam ga branio i uvek uveravao da je našinac, pa baš ako i Frankovića pomaže, to on u religioznom smislu za cerkve, škole etc... čini, ala zabadava." ${ }^{74}$ Pokušavajući ih razuvjeriti, Orešković javlja Brliću da je napisao "jedan list na Botića, ${ }^{75}$ ali koji sam i ovdašnjem up-

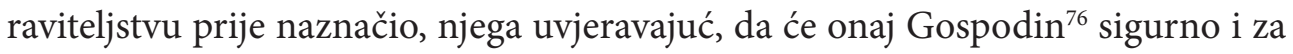
našu stvar kao i za tobože religioznu, rado nešto pridoneti. No prevario sam se. Gospodin Djakovački ili nemari ili je preveć mudar i vorsichtig." ${ }^{77}$

U ovo vrijeme Orešković je već prebjegao u Srbiju i odmah je primljen u vojsku te piše Andriji da je "za sad vrhovni zapovednik dobrovoljačke brigade, sasvim neodvisan i samo vojnome Ministarstvu u toliko podložen koliko od njega svu ratnu potrebu primam i dobivam. Plaću imam kao brigadir, a u protokolu upraviteljstva sam za sad, dok se što ne počme, kao Major upisan." ${ }^{78} \mathrm{U}$ jeku krize izazvane turskim bombardiranjem Beograda 1862. godine povjeren mu je zadatak da formira dobrovoljački korpus u Valjevu. I sam piše Brliću da njegov "Freikorps stoji u Valevu” i “imam pravo oficire koje oću u moj Corps primati i nevredne oćerivati, na moj Vorschlag, kojeg knezu predlažem geschehen die Beförderungen. Tako sam već dva Lieutenanta za kapetane naznačio, a knez i potverdio.”79 Moli Andriju da, ako može, "nekoliko dobri mladića iz Provinciale za moj Corps verbovati a ti ji uputi amo na me, mogli bi po svojoj sposobnosti ovde svoju sreću

\footnotetext{
70 HR-AOB, Pismo A. Oreškovića, kut. 21, sv. 10. Nedatirano no vjerojatno je iz ožujka ili travnja 1862. godine jer je već sljedeće pismo od 24. svibnja 1862. iz Šapca u Srbiji kamo je Orešković prebjegao. (Prijepis Ivan Brlić).

71 Agičić, Tajna politika Srbije, 109.

72 Usp. Krestić, Srpsko-hrvatski odnosi, 17. i Vučković, “Nacionalno-revolucionarna akcija Srbije”, 7.

73 Sebastijan Franković (1800. - 1864.), apostolski vikar u Bosni 1861. - 1864. godine.

74 HR-AOB, Pismo A. Oreškovića od 16. srpnja 1862., kut. 21, sv. 10. (Prijepis Ivan Brlić).

75 Luka Botić (1830.-1863.), obnašao je dužnost predstojnika biskupskoga imanja u Đakovu od 1853. do 1860. godine.

76 Biskup Strossmayer.

77 HR-AOB, Pismo A. Oreškovića od 16. srpnja 1862., kut. 21, sv. 10. (Prijepis Ivan Brlić).

78 HR-AOB, Pismo A. Oreškovića od 16. srpnja 1862., kut. 21, sv. 10. (Prijepis Ivan Brlić).

79 HR-AOB, Pismo A. Oreškovića od 16. srpnja 1862., kut. 21, sv. 10. (Prijepis Ivan Brlić).
} 
naći"80, a kako je Austrija tada punu pozornost stavila na sva sumnjivija kretanja u Vojnoj krajini, Orešković piše i da "u Granicu za sad ne diramo da Austria ne posumnja o njoj, tek u zadnje vreme zvaće se ko bude hteo doći, no ipak koji sami dogju, najmre izslužene Charge rado se primaju." ${ }^{11} \mathrm{Na}$ kraju pisma poručuje mu da piše u šiframa, a da njemu može dati ime Sava Savić. U sklopu povjerenoga mu zadatka da nastavi rad s razgranatom obavještajnom mrežom agenata, Orešković piše Brliću i kako je "ovi dana došao ovamo neki Franjo Mauri, Slovenac, rodom iz Gerca, ${ }^{82}$ koji je svršio teologiju u Zagrebu. Po njegovom izvestiju kojeg mi je podneo, Garašanin bi njega upotrebio kao stalna agenta u Albanii, kuda bi ga poslao, no pre svega rad bi saznati njegova prvašnja odnošenja i zanimanja i da nije možebit od austriske policie podmetnut. Za svoju iskrenost dokazati poziva se ovaj Mauri na kanonika Marića ${ }^{83}$, na paroka Kršnjavu ${ }^{84}$ u Orahovici, blizu Našica, na popa Pavlinovića ${ }^{85}$ u Dalmacii i još nekoje druge. Za njegovu prošlost kao i njegovu iskrenost saznati, molim te da ova lica radi njega što pre zapitaš (...)." ${ }^{\prime 6}$ Garašanin ga je na kraju poslao u Albaniju, no njegova misija bila je neuspješna pa je suradnja s njim ubrzo bila prekinuta. ${ }^{87} \mathrm{Iz}$ pisma koje je Orešković poslao Brliću 1865. godine vidi se da je Orešković i uz njegovu pomoć pokušavao dobiti otpust iz austrijskoga državljanstva te mu piše: “ja tražim otpust iz austriskog podaničtva koji, sada - pošto se je politika austriska u nešto slobodnije pokrenula - dobiti mogućim držim. U tom smislu predao sam svoju prošnju ovdašnjem Konsulatu, no rešenje tog odpusta spade na General Komandu u Zagrebu (...)." Moli ga da s tim u vezi on osobno ili preko svojih prijatelja intervenira kod majora Marasa. Otpust iz austrijskoga državljanstva i prijem u srpsko Orešković je ipak dobio tek 1868. godine. Na svoj položaj u Srbiji požalio se Andriji u pismu iz 1865. pišući mu: "sve gore biva, a kad će jedanput na bolje okrenuti se, to Bog zna. Kud se okreneš sve same laži a Garašanin najveća lažčina. Knez pako naveća kukavica. Od moga čina i zvanja nema ništa, dok nisam izradio što jim potrebno bijaše, lagaše i obećavaše a kad svrši pa jim predadoh onda moraše i svoje gluparie upotrebiti, meni pako rekoše da sam stranac, da se boje zaziranja od Austrie i Turske kad bi mi zvanje dali." ${ }^{99}$ Iz pisma se vidi da Garašanin i dalje nema povje-

\footnotetext{
${ }^{80}$ HR-AOB, Pismo A. Oreškovića od 16. srpnja 1862., kut. 21, sv. 10. (Prijepis Ivan Brlić).

81 HR-AOB, Pismo A. Oreškovića od 16. srpnja 1862., kut. 21, sv. 10. (Prijepis Ivan Brlić).

82 Gorica.

83 Josip Marić (1807. - 1883.), zagrebački kanonik.

84 Josip Kršnjavi (1823. - 1892.), rimokatolički župnik, stric Isidora Kršnjavoga.

${ }^{85}$ Mihovil Pavlinović (1831. - 1887.), političar i književnik, jedan od najistaknutijih predstavnika hrvatskoga narodnog preporoda i Narodne stranke u Dalmaciji.

${ }^{86}$ HR-AOB, Pismo A. Oreškovića od 14/26. prosinca 1865., kut. 21, sv. 10. (Prijepis Ivan Brlić).

87 Jakšić, Vučković, Spoljna politika Srbije, 241.

88 HR-AOB, Pismo A. Oreškovića od 3. prosinca 1865., kut. 21, sv. 10. (Prijepis Ivan Brlić).

89 HR-AOB, Pismo A. Oreškovića od 27. rujna/9. listopada 1865., kut. 21, sv. 10. (Prijepis Ivan Brlić). Pismo je objavljeno u: Artuković, "Pisma Antonija Oreškovića”, 132-133.
} 
renja u biskupa Strossmayera i želi da se "Krstić u povratku svome iz Pariza preko Pešte i Osjeka Štrosmajeru u Djakovo navrati, tamo kao moj prijatelj predstavi, u moje ime koješta što ja i ne znam dostavi i od Štrosmajera i neka uputstva za mene zamoli. Za tu cjel morade ja unapred Krstića kao mog vjernog prijatelja pismeno Štrosmajeru priporučiti." ${ }^{\prime 90}$ Stoga Orešković Strossmayeru preporuča oprez prema izaslaniku srpske Vlade jer "sva namjera dolaska Krstića u Djakovar sastoji se u tome da Štrosmajera iskuša. [...] ja te molim da odma kako ovo pismo dobiješ Štrosmajeru pišeš da Krstića kad k njemu dođe kao mog tobožnjeg prijatelja dobro primi, ali da bude na oprezu i da mu ne vjeruje. Štogod Krstić govorio bude, to neka Štrosmajer zna da je Garašaninovo uputstvo za koje ja ne znam." Moli da tom prilikom "Štrosmajer koješta Krstiću kaže, koje bi mene ovde važnijeg činilo i moj položaj olakšati moglo pošto sve što se s Krstićem tamo govorilo bude Garašaninu će se javiti a ja teško da što saznati budem mogao."92

Prepiska između Antonija Oreškovića i čelnih ljudi Kneževine Srbije s prvacima Narodne stranke i tajnim agentima u službi srpske Vlade te s važnim međunarodnim kontaktima koje je ostvario važan su izvor za istraživanje političkih prilika u razdoblju od 1866. do 1868. godine i odnosa Kneževine Srbije i Narodne stranke. Svoj doprinos u poznavanju tih odnosa i povezanosti Narodne stranke i Srbije, južnoslavenske ideje u hrvatskoj politici na njezinoj prekretnici u složenim unutrašnjim i vanjskopolitičkim prilikama kao i politike Srbije prema Hrvatskoj daju i pisma koje je Orešković, kao izravni i jedan od glavnih sudionika zbivanja, uputio Andriji Torkvatu Brliću. Narodna stranka pod vodstvom biskupa Strossmayera sve do Austrijsko-pruskog rata 1866. godine zalagala se za preuređenje Habsburške Monarhije na federalističkim osnovama. Porazom od Pruske kod Sadove u srpnju 1866. Monarhija je bila u temeljima poljuljana i postavljalo se i pitanje njezina opstanka. Kratko vrijeme poslije Sadove, unatoč naznakama da je car spreman udovoljiti zahtjevima Mađara, još je bilo neizvjesno hoće li se dvor odlučiti za federalizam ili dualizam. Sve do neuspjeloga sastanka slavenskih federalista u Beču u prvoj polovici kolovoza 1866. Strossmayer se nadao federalizmu. Potom se Narodna stranka okrenula pregovorima s Bečom, no već je bilo kasno jer se Beč, kao što je već rečeno, odlučio za dualizam i nagodbu s Ugarskom. No, uz javnu antidualističku politiku Narodna stranka istovremeno je vodila i tajnu politiku usmjerenu prema stvaranju zajedničke južnoslavenske države. Tajnu jer prihvatiti suradnju sa Srbijom znači napustiti legalne putove političke borbe i raditi na rušenju Monarhije. Po nalogu kneza Mihaila i Garašanina Antonije Orešković stupio je u kontakt s biskupom Strossmayerom u kolovozu 1866. godine. U izvješću podnesenome knezu Mihailu 25. kolovoza 1866. Orešković piše "da je gospodin Štrosmajer pristao na učinjen mu preko mene predlog od gospodina

${ }^{90}$ HR-AOB, Pismo A. Oreškovića od 27. rujna/9. listopada 1865., kut. 21, sv. 10. (Prijepis Ivan Brlić).

${ }^{91}$ HR-AOB, Pismo A. Oreškovića od 27. rujna/9. listopada 1865., kut. 21, sv. 10. (Prijepis Ivan Brlić).

${ }_{92}$ HR-AOB, Pismo A. Oreškovića od 27. rujna/9. listopada 1865., kut. 21, sv. 10. (Prijepis Ivan Brlić). 
Garašanina, tičući zajedničke radnje između Trojedne Kraljevine i Srbije da se osnuje jedna jugoslavenska država nezavisna i od Austrije i od Turske." ${ }^{93}$ Nadalje piše knezu da mu je "usmeno poručio da Vašoj Svjetlosti izjavim od njegove strane da ako se ozbiljno uzradi o tome da Vaša Svjetlost bude na čelu tog velikog preduzeća, on će ne samo na tu svrhu sav svoj upliv u Hrvatskoj i sve svoje sile uložiti, nego će biti gotov u svoje vreme i kao Vaš Minister javno Vas podpomoći u konačnom izvedenju istog dela. Tim obećanjem on misli da Vam daje najsigurnije jemstvo za lojalnost i postojanost njegove radnje." ${ }^{94} \mathrm{U}$ tome trenutku nije sklopljen poseban hrvatsko-srpski ugovor niti je utvrđen detaljni plan rada. Postignut je tek usmeni i načelni dogovor. Ubrzo nakon postignutoga usmenog sporazuma biskupa Strossmayera i srpske Vlade Garašaninu je, želeći se poslužiti biskupovim ugledom koji je uživao na Zapadu, zatrebala njegova suradnja u namjeri da pokrene pitanje predaje gradova. ${ }^{95}$ No, prije pokretanja toga pitanja trebalo je otkloniti sumnje Francuske koja je na Srbiju gledala kao na privjesak Rusije. Orešković piše Brliću da je dobio "od generala Tira ${ }^{96}$ pismo iz Pariza da ja do 10. januara imam u Pariz doći. [...] Od Garašanina dobit ću punomoćie kojim izjavljuje da podpuno poverenje meni poklanja za sve što ja u Parizu predlagao i ugovorio budem i da on moje mnjenje dieli.. ${ }^{\prime 7}$ Orešković pojašnjava razlog svoga odlaska u diplomatsku misiju i piše Andriji: "Francuska bi rada da se - pošto uvidja da se Turska dugo držat ne može - mjesto nje jedna snažna slavjanska država podigne no da ta ne bude izključivo pravoslavna, jer se u tom slučaju boje da bi suviše se Rusii priklanjala. Francuska bi rada da i katolički slavjanski element u toj novoj državi zastupan bude kako bi isti protivstajao svakom nagibanju pravoslavnog ka Rusii. [...] Zapad se boji Rusije da nas ne proguta i da se tako ne pruži do Adriatičeskog mora, na koji bi način onda svu Evropu dominirala. Za tomu doskočiti misli Zapad sa ujedinjenjem sviju Jugoslavena u jednu samostalnu državu, jaku barijeru protiv opasni namjera Rusije osnovati. [...] To ti je u glavnom stvar radi koje mene u Pariz zovu, jer misle da ću im ja kao katolik i Hrvat najiskrenije i najtočnije objašnjenje dati moći, dali se i kojim načinom ova jugoslavenska država podići može, a da Rusii ne nagiba." ${ }^{" 98}$ Moli Brlića da posreduje kod Strossmayera za preporuku u Parizu i da upotrijebi sve svoje "oštroumlje da od

${ }_{93}$ Pismo A. Oreškovića knezu Mihailu od 25. kolovoza 1866. godine u: Viktor Novak, "Jedno sporno pitanje iz srpskohrvatskih odnosa šezdesetih godina prošloga veka”, Istoriski časopis 1 (1949), br. 1-2: 188-189.

${ }^{94}$ Novak, "Jedno sporno pitanje iz srpskohrvatskih odnosa", 188-189.

95 Beograd, Kladovo, Smederevo, Soko, Šabac i Užice.

${ }^{96}$ István Türr (1825. - 1908.), posrednik i Oreškovićeva veza s mađarskom emigracijom i talijanskom Vladom.

${ }^{97}$ HR-AOB, Pismo A. Oreškovića od 24. studenoga/6. prosinca 1866., kut. 21, sv. 10. (Prijepis Ivan Brlić). Pismo je objavljeno u: Artuković, "Pisma Antonija Oreškovića”, 133-134.

${ }_{98}$ HR-AOB, Pismo A. Oreškovića od 24. studenoga/6. prosinca 1866., kut. 21, sv. 10. (Prijepis Ivan Brlić). 
Štrosmajera pismo za me dobiješ kojim on meni podpuno povjerenje poklanja"99 jer mu pored Garašaninove punomoći "treba sad jedno od Štrosmajera na koje bi se mnogo više u Parizu držalo nego Garašaninovo." ${ }^{100}$ Moli da mu Strossmayer da i uputu koje će se pridržavati u Parizu te umiruje "neka se ne boji da ću ga kompromitirati. Ja mu se zaklinjem da pismo neće iz moji ruku doći i samo ću ga princu Napoleonu pokazati i kad posao u Parizu svršim ja ću mu to pismo radi njegovog spokojstva odma povratiti." ${ }^{101}$ Baš u to vrijeme, u studenome 1866. izvršen je i pretres u biskupovu stanu i prema policijskim podacima u njegovim knjigama bi trebale biti bilješke o tome kakvu je djelatnost obavljao u interesu Rusije. ${ }^{102} \mathrm{U}$ istome pismu Orešković iznosi i svoj politički program i nada se da će ga podržati Francuska, Italija i Pruska. "Nastojavam da ako se na Jugu u mjesto Turske jedna nova država podići ima, tada ne bude srpska država nego slavjanska država. Zato težim i radim da bez učastija Hrvacke sama Srbija tu radnju ni odpočeti ne može. Ja želim kao što Štrosmajer želi sajedinjenje Jugoslavena dakle pre svega njiovo sporazumljenje onda zajedničku radnju. U tome će mene Francuska, Italija a i Prajska ${ }^{103}$ podpomagati, ali ja moram ove države uvjeriti da Hrvati tako šta žele i na to pristaju, bilo ovo sajedinjenje aneksija kraljevini ili odcepljenje Južni Slavjana od Austrije." ${ }^{104}$ Orešković je sljedećih mjeseci u nekoliko navrata tražio od Brlića da od biskupa pribavi spomenuto pismo. Sastavio je i obrazac po kojemu je Strossmayer trebao napisati pismo i poslao ga Andriji, no moli da mu ga ne šalje u Veneciju gdje je biskup boravio, nego da čeka "dok se kući vrati, poštom ga poslati bilo bi opasno." ${ }^{105}$ Kada ga je biskup i napisao, nije bio zadovoljan njegovim sadržajem i piše Andriji da biskupovo pismo "nije za ništa i ja se čudim kako predpostavljati možeš da ću s njime u Pariz putovati i tamo ga za naznačenu ti cjelj upotrebiti moći." 106 Žali se da ga Garašanin nije ni poslao u Pariz "radi toga što sadržaj pisma nije odgovarajući” i poručuje da tamo neće ni ići "ako mi Štrosmajer pismo boljeg sadržaja ne pošalje." ${ }^{107}$ Iako je Garašanin tada već bio smijenjen, Orešković je pisao Brliću da je sam Garašanin "sastavio pismo kakvo želi da ja dobijem od Štrosmajera a ja ti ga prilažem u prepisu. Ako Štrosmajer ne bi hteo

\footnotetext{
99 HR-AOB, Pismo A. Oreškovića od 24. studenoga/6. prosinca 1866., kut. 21, sv. 10. (Prijepis Ivan Brlić).

${ }^{100}$ HR-AOB, Pismo A. Oreškovića od 24. studenoga/6. prosinca 1866., kut. 21, sv. 10. (Prijepis Ivan Brlić).

${ }^{101}$ HR-AOB, Pismo A. Oreškovića od 24. studenoga/6. prosinca 1866., kut. 21, sv. 10. (Prijepis Ivan Brlić).

102 Šidak, Studije iz hrvatske povijesti, 336., bilj. 26.

${ }^{103}$ Pruska.

${ }^{104}$ HR-AOB, Pismo A. Oreškovića od 24. studenoga/6. prosinca 1866., kut. 21, sv. 10. (Prijepis Ivan Brlić) Pismo je objavljeno u: Artuković, "Pisma Antonija Oreškovića”, 133-134.

${ }^{105}$ HR-AOB, Pismo A. Oreškovića od 11/23. siječnja 1867., kut. 21, sv. 10. (Prijepis Ivan Brlić).

${ }^{106}$ HR-AOB, Pismo A. Oreškovića od 1/13. prosinca 1867.

${ }^{107}$ HR-AOB, Pismo A. Oreškovića od 1/13. prosinca 1867.
} 
izdati baš ovako kako ovo glasi ono neka bude barem njemu nalik." ${ }^{108} \mathrm{U}$ pismu za koje je Orešković tvrdio da ga je Garašanin sastavio, a što je biskup trebao napisati, stoji među ostalim: "program koji ste mi imali dobrotu saobštiti i koji u sebi sadrži vašu radnju u Srbiji o budućnosti Južnih Slavena u kojima pristojno položenje zauzimaju Hrvati sa Slavoniom i Dalmaciom, ja ga podpuno odobravam i u svemu se saglašavam sa Vašim plemenitim mislima. [...] Misao je sretna, koja se je u Srbiji izrodila i već usvojila i koja se u tome sastoji, da se svi Jugosloveni u jedan narod sliju i tim slivenjem sami sobom svoju budućnost osiguraju, bez uticaja ikoje strane sile. [...] Ja tim slobodnije odobravam Vašu radnju i pridružujem se istoj što u njoj stvar katolicizma, koga je poziv tako vispren i tako nuždan, ostaje uvjek nedodirnut u svojoj važnosti i svojem zadatku." ${ }^{109}$ Nezadovoljan kako se stvari odvijaju u vezi dizanja ustanka u Bosni i njezina oslobođenja, unatoč već ostvarenomu kontaktu i usmenomu sporazumu s Narodnom strankom i biskupom Strossmayerom, Orešković piše Brliću kako sve stoji po "starome, mnogo riječi a malo rada i budi uvjeren da kako poznajem okolnosti da neće ove godine ništa ni biti. Lažu samo svet i piskaraju po novinama nebili lakše do gradova došli (...)."110 Garašanin ga nije poslao u Pariz; ostavio ga je u Beogradu i dao mu zadatak da izradi ratni plan protiv Turske.

Orešković je izradio plan početkom ožujka 1867. godine i predviđao je suradnju i s Hrvatskom i Vojnom krajinom. Ustanak u Bosni podigle bi unaprijed pripremljene čete koje bi istovremeno upale iz Srbije, Slavonije, Hrvatske, Dalmacije i Crne Gore. Predložio je osnivanje tajnih odbora koji bi na austrijskome teritoriju bili potčinjeni Glavnomu odboru u Zagrebu. Kako bi se oslobođenje Bosne i Hercegovine, što je trebalo biti prva zajednička akcija Južnih Slavena, moglo uspješno provesti u djelo, bilo je potrebno izraditi i poseban tajni politički program zajedničke južnoslavenske politike Srba i Hrvata. Orešković je izradio nacrt programa, no Garašanin ga je prepravio i dopunio te mu konačnu verziju dao sredinom ožujka 1867. tako da je prijedlog programa poslan biskupu Strossmayeru krajem ožujka. ${ }^{111} \mathrm{U}$ programu koji je sastavio Orešković kao cilj zajedničke politike naznačeno je stvaranje južnoslavenske države koje bi se trebalo odvijati u etapama. Prva zajednička akcija Trojedne Kraljevine i Srbije trebala je biti usmjerena na oslobođenje Bosne i Hercegovine i sjedinjenje sa Srbijom. Na čelu oslobodilačkoga pokreta, za koji je predviđeno da počne u ljeto 1867., stoje Beograd i Zagreb "na kojima će se jugoslavenska stvar sva okretati. Između Beograda i Zagreba

\footnotetext{
${ }^{108}$ HR-AOB, Pismo A. Oreškovića od 1/13. prosinca 1867.

${ }^{109}$ HR-AOB, Prilog pismu A. Oreškovića od 1/13. prosinca 1867.

${ }^{110}$ HR-AOB, Pismo A. Oreškovića od 11/23. siječnja 1867.

${ }^{111}$ Usp. Jakšić, Vučković, Spoljna politika Srbije, 356-363. Program jugoslavenske politike koji je predložio Orešković, s Garašaninovim ispravkama i dopunama u cijelosti je objavljen u: Jakšić, Vučković, Spoljna politika Srbije, 494-504.
} 
mora biti vječito sporazumljenje." ${ }^{112}$ Budući da Beograd ima "svoju nezavisnu vladu i sva vojnička sredstva na raspoloženju, prirodan je centrum za diplomatičku i vojničku radnju. Otud će se sva ta radnja i rukovoditi ali uvjek u sporazumljenju sa Zagrebom." ${ }^{113}$ Međutim, Garašanin je u svome ispravku programa kao prvi cilj naznačio oslobođenje slavenskih pokrajina od turske vlasti te, kao i u svome Načertaniju iz 1844. godine, izbacio Oreškovićevo "ali uvjek u sporazumljenju sa Zagrebom" i umjesto toga unio "u čemu će ga Zagreb podpomagati" odbivši tako suradnju Hrvatske na ravnopravnim osnovama i svevši je na potpomaganje Srbije. Orešković je u programu predvidio i stvaranje triju glavnih odbora: u Osijeku za Slavoniju, u Makarskoj za Dalmaciju i u Zagrebu za Hrvatsku. Garašanin je ukinuo odbore u Osijeku i Makarskoj, a ostavio odbor u Zagrebu. Hrvatska je, prema programu, bila dužna izvršiti pripreme da bi se izvukla iz austrijske i ugarske državne zajednice i bez teškoća priključila saveznoj državi Južnih Slavena. Morala je "izbjegavati savez s Ugarskom i Bečom da bi imala za budućnost ruke sasvim slobodne." 114 Narodna stranka početkom travnja 1867. bez primjedbe je usvojila predloženi tajni jugoslavenski program u obliku kakav mu je u konačnoj redakciji dao Garašanin. O tome i Orešković u svojemu pismu izvještava Brlića. Piše mu da je Mrazović bio u Beogradu u Strossmayerovo ime i donio potvrdni odgovor na ponuđeni prijedlog srpske Vlade. Orešković ga je odveo Garašaninu "kome je izvjestne predloge stavio. Sporazumili smo se da solidarno postupamo." ${ }^{115} S$ druge strane, Garašanin se obvezao da će Srbija utjecati na sve "na koje upliva imamo da se na predstojećem Saboru tvrdo drže Štrosmajera koji će biti predstavnik naše zajedničke idee." ${ }^{116} \mathrm{U}$ istome pismu Orešković se iznova žali Brliću kako se i dalje ništa ne poduzima glede Bosne i "kako i dan danas stojimo pa gledamo skršteni ruku velikim dogadjajima u susret, koji će se po svoj prilici skorim u Evropi pojaviti." ${ }^{117}$ Izvještava Brlića da je knez Mihailo u Carigradu i da se nada da će neizvjesnost prestati kada se vrati "pa ćemo možda znati ili moći nekakvi politični pravac poprimiti po kojem ćemo dalje koracati i raditi." 118 Narodna stranka je u skladu s jugoslavenskim tajnim programom ugovorenim sa Srbijom odmah razvila živu tajnu aktivnost. Već je u svibnju osnovala Glavni odbor u Zagrebu na čelu s Mrazovićem. Orešković piše Brliću da će "srpska vlada

\footnotetext{
112 "Program jugoslovenske politike predložen od strane Garašanina Štrosmajeru (marta) 1867. god.", u: Jakšić, Vučković, Spoljna politika Srbije, 495.

113 “Program jugoslovenske politike predložen od strane Garašanina Štrosmajeru (marta) 1867. god.", u: Jakšić, Vučković, Spoljna politika Srbije, 496.

114 "Program jugoslovenske politike predložen od strane Garašanina Štrosmajeru (marta) 1867. god., u: Jakšić, Vučković, Spoljna politika Srbije, 495.

${ }^{115}$ HR-AOB, Pismo A. Oreškovića od 4/16. travnja 1867., kut. 21, sv. 10. (Prijepis Ivan Brlić). Pismo je objavljeno u: Artuković, "Pisma Antonija Oreškovića”, 135.

${ }^{116}$ HR-AOB, Pismo A. Oreškovića od 4/16. travnja 1867., kut. 21, sv. 10. (Prijepis Ivan Brlić).

${ }^{117}$ HR-AOB, Pismo A. Oreškovića od 4/16. travnja 1867., kut. 21, sv. 10. (Prijepis Ivan Brlić).

${ }^{118}$ HR-AOB, Pismo A. Oreškovića od 4/16. travnja 1867., kut. 21, sv. 10. (Prijepis Ivan Brlić).
} 
odsada samo sa time odborom prepiske i posla imati, a odbor će dalje po nalogima koji će se odavle slati u Trojednici i pograničnoj joj Bosni poslovati. [...] Ja sam uputio odbor u Zagrebu da s tobom stupi u sporazumljenje. On će trebati tvoga uputstva i tvoje pomoći." ${ }^{119}$ Narodna stranka je prema tajnome programu ugovorenome sa Srbijom u potpunosti uskladila svoj politički program i razvila aktivnost koja je za konačni cilj imala odcjepljenje od Habsburške Monarhije i sjedinjenje s ostalim Južnim Slavenima u nezavisnu južnoslavensku državu. Stoga je u skladu sa zajedničkim jugoslavenskim programom i u duhu hrvatsko-srpskoga zbližavanja Hrvatski sabor u svibnju 1867. jednoglasno donio odluku da "Trojedna kraljevina priznaje narod srpski, koji u njoj stanuje, kao sa narodom hrvatskim istovjetan i ravnopravan." 120 Još u siječnju iste godine Sabor je za službeni jezik proglasio "hrvatski ili srpski" preinačivši tako naziv "jugoslavenski jezik" kojeg je bio prihvatio 1861. godine. Hrvatski sabor sazvan u svibnju imao je zadaću da pitanje odnosa s Ugarskom napokon privede kraju. Prethodno je car Franjo Josip I. krajem travnja 1867. pozvao biskupa Strossmayera u audijenciju i zatražio od njega da uloži svoj utjecaj kako bi Sabor usvojio mađarski program o Hrvatskoj ili da izostane iz saborskih zasjedanja, a ako se ne pokori, napomenuo je da će upotrijebiti silu. Strossmayer se morao povući te je otišao u Pariz. I Ivan Mažuranić je, kao i Strossmayer, bio prisiljen povući se iz Sabora pod pritiskom i na taj način olakšati donošenje nagodbe s Ugarskom. Unatoč tomu Hrvatski sabor je, s obzirom da odnosi s Ugarskom još nisu bili uređeni, odbio poslati svoje izaslanike u Ugarski sabor radi sudjelovanja na krunidbi Franje Josipa I. Krajem svibnja Sabor je i raspušten.

I dok se hrvatska strana vjerno držala ugovorenoga sporazuma sa srpskom Vladom i zajedničkoga jugoslavenskog programa, srpska je Vlada taj program uskoro napustila. Radikalni zaokret u politici kneza Mihaila dogodio se krajem kolovoza 1867. u Ivanki na sastanku s grofom Andrássyjem. Tom prilikom knezu je obećao Bosnu u zamjenu da odustane od dizanja ustanka u Bosni. Tražio je i da se Srbija uzdržava od poticanja neprijateljskoga držanja ugarskih Srba prema ugarskoj Vladi i da ih umiruje. ${ }^{121}$ Orešković piše Brliću da "vlada neće ništa da znade za bivši program i isto tako ništa za trojednicu. Na zahtevanje Mrazovića da mu se dade odlučan odgovor nehtedoše ništa odgovoriti, nego predamnom izjasniše se da Hrvatska u smotrenju nagodbe sa Magjarskom radi što joj drago, Srbija ne može tu nikakovi uputstava, a još manje kakove novčane pomoći dati; isto tako i radi priugotovljenja ustanka u Bosnoj neće ništa da znadu ništa. [...] Po svemu mogo bi ti kao izvjestno kazati da ste Magjarima izdati pod uslovom da oni puste Srbiji slobodne ruke u Turskoj. Radi toga bijaše grof Zići dva tri puta ovdje kod

\footnotetext{
${ }^{119}$ HR-AOB, Pismo A. Oreškovića od 11/25. srpnja 1867.

120 Šidak, Studije iz hrvatske povijesti, 336.

${ }^{121}$ O sastanku u Ivanki vidi: Jakšić, Vučković, Spoljna politika Srbije, 396-403. Krestić, Hrvatsko-ugarska nagodba, 366-383. Ciliga, Slom politike Narodne stranke, 37.
} 
knjaza. Da ćemo prevareni biti to je izvjestno."122 Grof Edmund Zichy dolazio je u Beograd knezu Mihailu kao austro-ugarski izaslanik s porukom da se nada da Srbija neće dizati ustanak u Bosni i da će se zadovoljiti dobivanjem gradova. ${ }^{123}$ Gradove je, na zahtjev velikih sila, Turska predala knezu Mihailu u travnju 1867. nakon njegova povratka iz Carigrada, što je bio uspjeh srpske politike i vodilo je poboljšanju odnosa s Turskom.

Međutim, Orešković nije htio odustati od započetih priprema za ustanak. Kada se uvjerio da od akcije sa Srbijom neće biti ništa, počeo je raditi na svoju ruku i bez znanja srpske Vlade. Namjeravao je akciju nastaviti uz potporu Pruske i Italije. I piše Brliću da je "u tom smotrenju neke korake poduzeo [...] Ja mislim da ćemo moći Srbiji u prkos nešto poduzeti u Bosni i ti to znaš, Jandro, da sam ja pre devet godina pobunio Bosnu sa pet stotina forinti na tu cjelj od tebe dobivenih. Treba samo odvažnosti, meni je ne fali, ali ne budite kukavice ni vi." ${ }^{124} \mathrm{U}$ istome pismu Orešković na kraju moli Andriju da bude oprezan u pismima i da dobro šifrira ona koja su samo za njega. Uz Garašaninovu dozvolu Orešković je preko pruskoga konzula u Beogradu pokušao za akciju u Bosni osigurati podršku Pruske. Beč je saznao za pregovore i knez je Garašanina bez objašnjenja razrješio dužnosti. Orešković je i Mrazovića obavijestio da je Srbija odustala od ugovorenoga programa i "neće ništa da protiv Turske poduzima". ${ }^{125}$ No, Mrazović i dalje nije vjerovao, teško se mirio s tim da je Srbija odustala od sporazuma i dotadašnje politike te piše Oreškoviću: "Ja se nikako ne mogu sprijateljiti s mišlju da se srpska vlada odriče akcije u Bosnoj, jer bi to po mojem mnenju, značilo odreći se bitnoga uvjeta za opstanak knjaževine Srbske. Ako Bosnu i Hercegovinu zauzme Austrija, ili recimo Ugarska, Srbija prestaje biti samostalna država." ${ }^{126}$ Nadao se da je tek izgubila povjerenje u Oreškovića i Brlića te da s njima više nije htjela surađivati, nego nastaviti rad s drugim agentima. Mrazović ogorčen piše: "Mi smo ovdje upravo sa uzmaka srbske vlade od ugovorenog programa dospjeli u mnogo nepovoljnije okolnosti, nego bi to bilo kad se ne bi bili pouzdavali u političku pronicavost srpske vlade, narodni ponos srbskog plemena i odvažnosti knjaza Mihaila. Naprama ugovorenu programu uzesmo pravac za svoj politički rad ovdje, koji se mogao izdati kad je zajednički program izdan. Uslied toga su neki važni faktori morali odstupiti za neko vrieme od političkog rada. Izdajom zajedničkog progra-

\footnotetext{
${ }^{122}$ HR-AOB, Pismo A. Oreškovića od 18/30. prosinca 1867., kut. 21, sv. 10. (Prijepis Ivan Brlić). Pismo je objavljeno u: Artuković, "Pisma Antonija Oreškovića”, 136-138.

${ }^{123}$ Usp. Krestić, Srpsko-hrvatski odnosi, 57. i Vučković, "Nacionalno-revolucionarna akcija Srbije”, 14.

${ }^{124}$ HR-AOB, Pismo A. Oreškovića od 18/30. prosinca 1867., kut. 21, sv. 10 (Prijepis Ivan Brlić). Pismo je objavljeno u: Artuković, "Pisma Antonija Oreškovića”, 136-138.

${ }^{125}$ Pismo A. Oreškovića Matiji Mrazoviću od 15/27. siječnja 1868. objavljeno u: Korunić, "Jugoslavenska ideja u hrvatskoj politici", 94-95. i Vera Ciliga, "Narodna stranka i južnoslavensko pitanje 1866-1870.," Historijski zbornik 17 (1964), br. 1-4: 87-88.

${ }^{126}$ Mrazovićevo pismo Oreškoviću iz veljače 1868. godine objavljeno u: Korunić, “Jugoslavenska ideja u hrvatskoj politici", 95-97.
} 
ma poremećen je naš poseban program. Bit će borbe, muke i patnje, i trebat će vremena da se svrati sav rad u novu kolotečinu." ${ }^{127}$

Upravo na biskupa Strossmayera mogu se najviše odnositi ove Mrazovićeve riječi: “neki važni faktori morali odstupiti za neko vrieme od političkog rada”. Biskupov položaj postao je vrlo kritičan i poslije povratka iz Francuske bio je pod stalnim nadzorom. U to vrijeme Andrássyju je predana i biskupova prepiska s knezom Mihailom. "Ta prepiska došla je do ruku Andrašija nesumnjivo već za života Mihailova što samoj stvari daje još mračniji i izdajničkiji vid. Rački i Štrosmajer bili su mišljenja da se to dogodilo tek posle Mihailovog ubistva. Međutim, to je moralo da bude, kao što sam dokazao, još za života Mihailova, i to upravo 1867." 128 O ugroženosti njegovoga položaja svjedoči i činjenica da je Brlić zamolio srpsku Vladu da primi Strossmayera kao apostolskoga vikara u Srbiji ako bude morao napustiti Đakovo. ${ }^{129}$ Orešković piše Brliću kako je "prezident ministerstva Nikola ${ }^{130}$ veliki magarac ne uvigjajuć veliki značaj tvoga predloga glede Štrosmajera našao se je u čudu kako ti takovu ludoriju samo predlagati možeš, pa je predlog prosto odbio. Pismo si nije dao ni pročitat veleć da te stvari iz Hrvatske nemaju interesa za njega." ${ }^{131}$ Brlić je to očito učinio bez biskupova znanja. U pismu iz veljače 1868. Orešković piše kako je "kao najveću tajnu saobštio mi je vojeni minister ${ }^{132}$ da je Štrosmajer pisao knezu, da on nije opunomoćio nikoga da ono pitanje radi njegovog preseljenja u Biograd srpskoj vladi stavi i da on takvo što nikada nije ni pomislio." ${ }^{33}$

U studenome i prosincu 1867. godine održavali su se izbori za Hrvatski sabor koji je trebao definirati Hrvatsko-ugarsku nagodbu. Izbori su se održavali uz veliki pritisak vlasti kojoj Narodna stranka, u očekivanju akcije u Bosni sukladno ugovorenome programu sa Srbijom, nije dala neki organiziraniji otpor. ${ }^{134}$ Narodnjaci su doživjeli težak poraz od unionista i unionistička većina sklopila je Nagodbu s

\footnotetext{
${ }^{127}$ Mrazovićevo pismo Strossmayeru iz veljače 1868. objavljeno u: Ciliga, "Narodna stranka i južnoslavensko pitanje”, 89-90.

${ }^{128}$ Novak, "Jedno sporno pitanje iz srpskohrvatskih odnosa", 195. Navodi da je prepisku predao Milivoje Blaznavac. Pridodaje i Šišićevo mišljenje da je Blaznavac predao Strossmayerova pisma Benjaminu Kállayu u periodu od 1868. do 1872. godine. Novak navodi i da je prema izjavama svećenika, kojega je Strossmayer preporučio Mihailovoj supruzi, kneginji Juliji, biskupova pisma caru predao sam knez Mihailo. Jovan Subotić spominje da je zahvaljujući Blaznavcu kompromitirajuće Strossmayerovo pismo dospjelo u Andrássyjeve ruke i da je biskupa od progona spasilo samo to što je u pitanju bio prijepis, a ne original. Usp. Viktor Novak, "Kako je i zašto nestala prepiska između kneza Mihajla i Štrosmajera”, Politika (Beograd), 6, 7, 8 i 9. 1. 1935., 13. i Ciliga, Slom politike Narodne stranke, 56., bilj. 17.

${ }^{129}$ Usp. Ciliga, Slom politike Narodne stranke, 56.

${ }^{130}$ Nikola Hrstić.

${ }^{131}$ HR-AOB, Pismo A. Oreškovića od 18/30. prosinca 1867., kut. 21, sv. 10. (Prijepis Ivan Brlić). Pismo je objavljeno u: Artuković, "Pisma Antonija Oreškovića”, 136-138.

${ }^{132}$ Milivoje Blaznavac.

${ }^{133}$ HR-AOB, Pismo A. Oreškovića od 21. veljače/4. ožujka 1868., kut. 21, sv. 10. (Prijepis Ivan Brlić). Pismo je objavljeno u: Artuković, "Pisma Antonija Oreškovića”, 138.

${ }^{134}$ Ciliga, Slom politike Narodne stranke, 58-59.
} 
Ugarskom. Kombinacije oko zajedničkoga programa sa Srbijom Narodna stranka napustila je nakon ubojstva kneza Mihaila u lipnju 1868. godine.

Orešković očito nije izgubio povjerenje u Srbiju ni nakon teškoga razočaranja i odustajanja Srbije od zajedničkoga programa. Dapače, Srbiji je davao prednost u zajedničkoj akciji na budućemu programu ujedinjenja. U jednome opširnom pismu Brliću od 21. rujna 1867. godine Orešković iznosi teške riječi na račun Hrvata. Ismijavao se na račun njihove uglađenosti, kulture i obrazovanosti, a srpske sirovosti. Piše Brliću: "Vi ste ljudi pametni pa Vas je teško prevariti, Vi ste ljudi fini i civilizovani pa Vas svak uvažava, a prostačka sila bježi od dodira s Vami." ${ }^{135} \mathrm{Na}$ ironičan način daje do znanja kako Hrvati u svome Saboru govore lijepo i kićeno, ali su ti govori isprazni i nemaju nikakvoga učinka. "Kod Vas, u Vašim zborovima što no ji zovete saborima, tu ti je slobodna reč, govorite baš kako Vam srce diktira i zaista diviti se je Vašem junačtvu (...)", ${ }^{136}$ no nadalje pita Orešković: "koga ste do sada ugrizli il lajanjem Vašim poplašili? Ta znadu u Pešti i Beču ljudi što su Vam gospodari da doklem god na sva usta govorite da i ništa ozbiljnog niste sposobni uraditi." 137 Poručuje kako su Hrvati najobičnije sluge Nijemaca i Mađara koji ih ucjenjuju i podcjenjuju. "Što imate svoga Vi jadne sluge još jadniji gospodara [...] niko Vas ne voli, a svako vas mrzi. Gospodari Vaši sami Vas preziru. Istina kadkad ali i to kad ji tišti nevolja sa strane, pokažu Vam se u toliko milostivi, da vas udostoje snizhoditeljnog prijatnog pogleda. Kada se tako slučajno dogodi, a Vi odma - zanešeni tom vanrednom milošću - zaurlate pesme pobedonosne." ${ }^{138}$ Ističe da politika koju Srbija vodi svojim primitivnim i grubim metodama rada ima uspjeha, a da je rad Hrvata neplodan jer Srbiji "nije stalo samo do senke i pukog titranja. Kod nas se ne smatra skupština školom govorničkom, ona nam je nešto uzvišenijega, ona nam je stožer sveobšteg narodnog prava. Nitko ne dolazi u nju vetrenjastom težnjom da pokaže praznu rečitost, nego da učestvuje u rešavanju najozbiljnijeg narodnjeg i državnog rada. I vjeruj mi, što se rješi, ako i sa malo, ali ozbiljni reči, to ti se i izvrši." 139

\section{Zaključak}

U Arhivu obitelji Brlić sačuvano je 39 pisama Antonija Oreškovića Andriji Torkvatu Brliću. Pisma su nastala u razdoblju od 1857. do 1868. godine. Važnost i povijesna vrijednost pisama kao povijesnoga izvora jest velika. Iz njih vidimo razinu nacionalne svijesti ovoga ličkog vojnog časnika. On se jasno izjašnjava kao Hrvat i katolik (pismo u studenome 1866.) pa na toj činjenici temelji i obrazlaže

\footnotetext{
${ }^{135}$ HR-AOB, Pismo A. Oreškovića od 21. rujna 1867., kut. 21, sv. 10. (Prijepis Ivan Brlić).

${ }^{136}$ HR-AOB, Pismo A. Oreškovića od 21. rujna 1867., kut. 21, sv. 10. (Prijepis Ivan Brlić).

${ }^{137}$ HR-AOB, Pismo A. Oreškovića od 21. rujna 1867., kut. 21, sv. 10. (Prijepis Ivan Brlić).

${ }^{138}$ HR-AOB, Pismo A. Oreškovića od 21. rujna 1867., kut. 21, sv. 10. (Prijepis Ivan Brlić).

${ }^{139}$ HR-AOB, Pismo A. Oreškovića od 21. rujna 1867., kut. 21, sv. 10. (Prijepis Ivan Brlić).
} 
čak i svoj politički program. U njima, nadalje, možemo naći vrijedne podatke važne za svakodnevni život korespondenata. Iz pisama je vidljivo prisno prijateljstvo koje je povezivalo Oreškovića s Andrijom i njegovom obitelji. Zabrinutost za prijateljevo zdravlje (Andrija je dugo pobolijevao.) česta je tema Oreškovićevih pisama. Raduju se zajedno berbama grožđa koje su u brodskoj povijesnici ostale nezaboravne. Članovi obitelji međusobno se posjećuju i rado su viđeni gosti.

Pisma su važna i kao izvor za rekonstrukciju podataka iz životopisa, ponajprije Antonija Oreškovića. U njima govori o vrlo važnim političkim događajima u razdoblju od 1857. do 1868. godine i svojoj ulozi u tim događajima. Orešković se stavio tada potpuno na raspolaganje srpskoj Vladi. Iz tih pisama vidimo da je njegova uloga u organizaciji ustanka u Bosanskoj Posavini 1858. znatna. To je, doduše, u suprotnosti s onim što je kasnije u svojim sjećanjima (Malo više svetlosti) priznavao. Možda i zbog nepripremljenosti ustanka i njegova kraha.

Temeljna vrijednost ovih pisama jest što u njima imamo opis događanja oko pripreme zajedničkoga plana srpske Vlade i Narodne stranke pod vodstvom biskupa Strossmayera i Matije Mrazovića, zajedničke vojne akcije za oslobađanje i stvaranje zajedničke države slavenskih naroda neovisne i od Habsburške Monarhije i od Osmanskoga Carstva. Antonije Orešković kao sudionik ovih događanja jasno svjedoči da je srpska Vlada odustala od planirane zajedničke akcije. Vjerodostojnost ovih pisama potvrđuju i drugi izvori (na primjer pisma Matije Mrazovića, također sudionika). Sam razvoj događaja potvrdio je istinitost riječi Antonija Oreškovića kao upućenoga i vjerodostojnoga svjedoka. Iz ovih pisama jasno vidimo Oreškovićev politički program: on je išao za tim da "ako se na Jugu u mjesto Turske jedna nova država podići ima, tada ne bude srpska država nego slavjanska država. Zato težim i radim da bez učastija Hrvacke sama Srbija tu radnju ni odpočeti ne može." ${ }^{140}$ Znamo da je iste političke nazore dijelio i biskup Strossmayer.

Već sama činjenica da su se istraživači, koji su se bavili problemima 50-ih i 60-ih godina 19. stoljeća, koristili pismima Antonija Oreškovića Andriji Torkvatu Brliću, govori o njihovoj važnosti. Na žalost, ne postoji životopis posvećen Oreškoviću. I budući njegov biograf neće moći nikako zaobići ovu vrijednu prepisku koja se čuva u Arhivu obitelji Brlić u Slavonskome Brodu.

Antonije Orešković bio je, kao što je više puta istaknuto, tajni agent srpske Vlade kao i njegov prijatelj Andrija Torkvat Brlić. Obojica su bila u važnome razdoblju povijesti i posrednici u pregovaranju između srpske Vlade i Narodne stranke. Poznanstvo i veza ove dvojice ljudi i njihova korespondencija, kao izravnih sudionika, daju važan doprinos poznavanju odnosa Narodne stranke s Kneževinom Srbijom i posljednično tomu razumijevanja nepovoljnoga ishoda Hrvatsko-ugarske nagodbe za hrvatsku stranu, ali i odnosa srpske politike prema Hrvatskoj.

${ }^{140}$ HR-AOB, Pismo A. Oreškovića od 24. studenoga/6. prosinca 1866., kut. 21, sv. 10. (Prijepis Ivan Brlić). Pismo je objavljeno u: Artuković, "Pisma Antonija Oreškovića”, 133-134. 
U trenutcima kada su se 1867. godine stvarali temelji državnoga preuređenja Habsburške Monarhije, koje će potrajati sve do njezine propasti, a što je dugoročno određivalo i položaj Hrvatske, Narodna stranka svoje težište interesa nije stavila na događanja u Monarhiji, nego ih je usmjerila na vanjskopolitička zbivanja od kojih je očekivala rješavanje hrvatskoga pitanja. Ključno je to što su Narodna stranka i biskup Strossmayer, u to presudno vrijeme za Hrvatsku, svoju politiku podredili ugovorenomu programu sa Srbijom s ciljem stvaranja nezavisne južnoslavenske države. $U$ to su uložili sve svoje snage potpuno zanemarivši ostale frontove očekujući da će se Srbija držati ugovorenoga programa. Nepovoljni uvjeti Hrvatsko-ugarske nagodbe izravan su rezultat vezivanja Narodne stranke za Srbiju koja se je povukla iz ugovora. Povlačenje Srbije za Narodnu stranku nije značilo samo odustajanje od zajedničkoga programa, nego i mijenjanje politike u Hrvatskoj. Pisma Antonija Oreškovića kao izravnoga sudionika ovih događanja o tome jasno svjedoče i moraju se uzeti kao ozbiljan i vjerodostojan izvor kod proučavanja ovih važnih događanja.

Veza sa Srbijom znatno je oslabila i biskupa Strossmayera, jednu od najvažnijih osoba tadašnjega hrvatskog političkog života. Za to vrijeme knez Mihailo je slijedio, kao što je i normalno za jednoga političara, interese Srbije na čijemu je čelu bio i pri tome praktički eliminirao Strossmayera kao politički relevantnu osobu predajući pisma, koja je Strossmayer njemu pisao, osobno caru Franji Josipu ili njegovu ministru Andrássyju. Ima različitih tumačenja u historiografiji u vezi $s$ tim kako su biskupova pisma dospjela u nepozvane ruke. No, sasvim je nevažno tko ih je i komu ih je dao. Knez Mihailo Austriju je smatrao glavnim neprijateljem za širenje Srbije. Stoga je u Mađarima vidio saveznike i vezao se uz Ugarsku koja je trebala Austriju spriječiti u njezinu širenju na istok.

Antonije Orešković pripada onim mnogobrojnim Hrvatima koji su tražili rješenje hrvatskoga pitanja na mjestu na kojemu ga nisu mogli naći. Dilemu "bi li k slavstvu ili ka hrvatstvu" u to je vrijeme već riješio Ante Starčević. Stoga politički rad u koji je uloženo mnogo truda, stradanja te materijalnoga i velikoga intelektualnog i duhovnoga potencijala generacija, od Antonija Oreškovića, Andrije Torkvata Brlića, Strossmayera, Račkoga, do Supila, Meštrovića, Ivane Brlić Mažuranić i na kraju do Josipa Broza, treba ocijeniti nedjelotvornim i za Hrvatsku štetnim. 


\section{Arhivi}

Hrvatska - Arhiv obitelji Brlić u Slavonskome Brodu, kut. 21, sv. 10 - Pisma Antonija Oreškovića Andriji Torkvatu Brliću (Prijepis Ivana Brlića) (HR-AOB-Pisma A. Oreškovića).

\section{Objavljeni izvori i literatura}

Agičić, Damir. Tajna politika Srbije u XIX. stoljeću. Zagreb: AGM, 1994.

Artuković, Mato. "Arhiv obitelji Brlić u Slavonskom Brodu”. Muzeologija 43-44 (2006 - 2007): 211-226.

Artuković, Mato. "Pisma Antonija Oreškovića". Vijesti: godišnjak Muzeja Brodskog Posavlja 8 (1994): 131-138.

Bogdanov, Vaso. "Prilog upoznavanju uloge Andrije Torkvata Brlića u revoluciji 1848.-49.”. Historijski zbornik 2 (1949), br. 1-4: 165-176.

Brešić, Vinko, prir. Autobiografije hrvatskih pisaca. Zagreb: AGM, 1997.

Brlić, Ignjat Alojzije. Pisma sinu Andriji Torkvatu Brliću 1836-1855. Knjiga I. Zagreb: Hrvatski izdavalački bibliografski zavod, 1942.

Brlić, Ignjat Alojzije. “Uspomene na stari Brod”. Svezak III. Vijesti: godišnjak Muzeja Brodskog Posavlja 7 (1983): 25-59.

Brlić-Mažuranić, Ivana. Iz Arhiva obitelji Brlić u Brodu na Savi (Uvod $k$ zbirci starih pisama od god. 1848.-1852.). Pretiskano iz Obzora. Zagreb: Tipografija d.d., 1934.

Ciliga, Vera. "Narodna stranka i južnoslavensko pitanje (1866-70)". Historijski zbornik 17 (1964), br. 1-4: 85-114.

Ciliga, Vera. Slom politike Narodne stranke (1865-1880). Zagreb: Matica hrvatska, 1970.

Jakšić, Grgur; Vučković, Vojislav. Spoljna politika Srbije za vlade kneza Mihaila (Prvi balkanski savez). Beograd: Istorijski institut, 1963.

Jovanović, Slobodan. Druga vlada Miloša i Mihaila (1858-1868). Beograd: Izdavačka knjižara Gece Kona, 1923.

Kaminski, Martin. "Ban, Matija, pjesnik, dramatičar, političar i publicist (18181903)". U: Hrvatski biografski leksikon, svezak 1, 408-411. Zagreb: Jugoslavenski leksikografski zavod "Miroslav Krleža”, 1983.

Kauzlarić, Snježana. "Razmišljanja o baštini: Kuća Brlić u Slavonskom Brodu i Ivana Brlić Mažuranić”. Informatica museologica 45-46 (2014 - 2015): 68-81.

Korunić, Petar. “Jugoslavenska ideja u hrvatskoj politici 1866-1868.". Zbornik Zavoda za povijesne znanosti Istraživačkog centra JAZU 11 (1981): 1-107. 
Korunić, Petar. "Prilog poznavanju jugoslavenske ideje u hrvatskoj politici 18681874.. Časopis za suvremenu povijest 12 (1980), br. 3: 57-83.

Krestić, Vasilije. Hrvatsko-ugarska nagodba 1868. godine. Beograd: Srpska akademija nauka i umetnosti, 1969.

Krestić, Vasilije. Iz istorije Srba i srpsko-hrvatskih odnosa. Beograd: Beogradski izdavačko-grafički zavod, 1994.

Krestić, Vasilije. Srpsko-hrvatski odnosi i jugoslovenska ideja 1860-1873. Beograd: Narodna knjiga, 1983.

Maixner, Rudolf. Andrija Torkvat Brlić emisar bana Jelačića u Francuskoj. Iz Arhiva obitelji Brlić. Knjiga IV. Prevela Zora Milčić-Brlić. Zagreb: Tipografija d.d., 1939.

Marković, Mirko. Brod: Kulturno-povijesna monografija. Slavonski Brod: Matica hrvatska, Ogranak Slavonski Brod, 1994.

Melnik, Tatjana. "Knjižnica obitelji Brlić". U: Zbornik o Andriji Torkvatu Brliću. Radovi znanstveno-stručnog skupa održanog 14. studenoga 2008. u Slavonskom Brodu, ur. Dinko Župan, 217-235. Slavonski Brod: Hrvatski institut za povijest, Podružnica za povijest Slavonije, Srijema i Baranje, 2012.

Miličević, Jovan. "Srbija 1839-1868". U: Istorija srpskog naroda, knj. V-1: Od Prvog ustanka do Berlinskog kongresa 1804-1878, ur. Vladimir Stojančević, 249301. Beograd: Srpska književna zadruga, 1981.

Novak, Viktor. "Jedno sporno pitanje iz srpskohrvatskih odnosa šezdesetih godina prošloga veka”. Istoriski časopis 1 (1949), br. 1-2: 181-198.

Novak, Viktor. "Kako je i zašto nestala prepiska između kneza Mihajla i Štrosmajera”. Politika (Beograd), 6, 7, 8 i 9. 1. 1935., 13.

Orešković, Antonije. Malo više svetlosti povodom brošure "Knjaz Mihailo i zajednička radnja balkanskih naroda". Beograd: Štamparija Svetozara Nikolića, 1895.

Popov, Čedomir. "Garašanin, Ilija, državnik, političar (1812-1874)”. U: Srpski biografski rečnik, svezak 2, 616-624. Novi Sad: Matica srpska, 2006.

Popov, Čedomir. “Srbija 1868-1878”. U: Istorija srpskog naroda, knj. V-1: Od Prvog ustanka do Berlinskog kongresa 1804-1878, ur. Vladimir Stojančević, 303421. Beograd: Srpska književna zadruga, 1981.

Popović, Radomir J. "Marinović, Jovan, državnik, političar, diplomata (18211893)". U: Srpski biografski rečnik, svezak 6, 86-88. Novi Sad: Matica srpska, 2014.

Samardžić, Momir. "Kovačević, Tomo, franjevac, poverenik srpske vlade (18201863)”. U: Srpski biografski rečnik, svezak 5, 146-147. Novi Sad: Matica srpska, 2011.

Stanković, Mladen. Arhiv obitelji Brlić. Slavonski Brod: GRO “Plamen”, 1987. 
Stojančević, Vladimir. "Srpska nacionalna revolucija i obnova države od kraja XVIII. veka do 1839.” U: Istorija srpskog naroda, knj. V-1: Od Prvog ustanka do Berlinskog kongresa 1804-1878, ur. Vladimir Stojančević, 5-158. Beograd: Srpska književna zadruga, 1981.

Šidak, Jaroslav. Studije iz hrvatske povijesti XIX stoljeća. Zagreb: Grafički zavod Hrvatske, 1973.

Šidak, Jaroslav. Studije iz hrvatske povijesti za revolucije 1848-49. Zagreb: Liber, 1979.

Šimunić, Petar. "Načertanije"- Tajni spis srpske nacionalne i vanjske politike, 2. izdanje, uredio Željko Krušelj. Zagreb: Globus, 1992.

Švoger, Vlasta. Ideali, strast i politika. Život i djelo Andrije Torkvata Brlića. Zagreb; Slavonski Brod: Hrvatski institut za povijest, Podružnica za povijest Slavonije, Srijema i Baranje, 2012.

Valentić, Mirko. "Prva programska formulacija velikosrpske ideje". U: Izvori velikosrpske agresije, prir. Bože Čović, 41-64. Zagreb: August Cesarec; Školska knjiga, 1991.

Vučković, Vojislav. "Nacionalno-revolucionarna akcija Srbije u Vojnoj granici”. Zbornik Matice srpske: Serija društvenih nauka 9 (1954): 5-25.

Vučković, Vojislav. "Orešković, Antonije, pukovnik (1829-1906)”. U: Enciklopedija Jugoslavije, svezak 6, 388. Zagreb: Jugoslavenski leksikografski zavod, 1965.

Żurek, Piotr. Poljska i Poljaci u životu Josipa Jurja Strossmayera. Slavonski Brod: Hrvatski institut za povijest, Podružnica za povijest Slavonije, Srijema i Baranje, 2008. 
Ivana Marijic

Letters of Antonije Orešković in the Brlić Family Archive as a Historical Source

\section{Summary}

The Brlić family archive preserves letters written by Antonije Orešković to Andrija Torkvat Brlić from 1857 to 1868 . Their acquaintance and correspondence were fundamental to the revival of the relations between the People's Party and the Principality of Serbia in a crucial period of the final state transformation of the Habsburg Monarchy in 1867, which also determined Croatias position in the long run. During that decisive period, the People's Party and Bishop Strossmayer subordinated their policies to a contractual program with Serbia aimed at creating an independent South Slavic state.

Keywords: Antonije Orešković, Andrija Torkvat Brlić, People’s Party, Bishop Strossmayer, Principality of Serbia, Prince Mihailo Obrenović, Ilija Garašanin, South Slavic state

* Ivana Marijić, Antuna Barca 5, 35000 Slavonski Brod, Croatia, E-mail: ivana_mar@yahoo.com 